\title{
The Potential Effect of Future Energy-Efficiency and Emissions-Improving Technologies on Fuel Consumption of Heavy Trucks
}

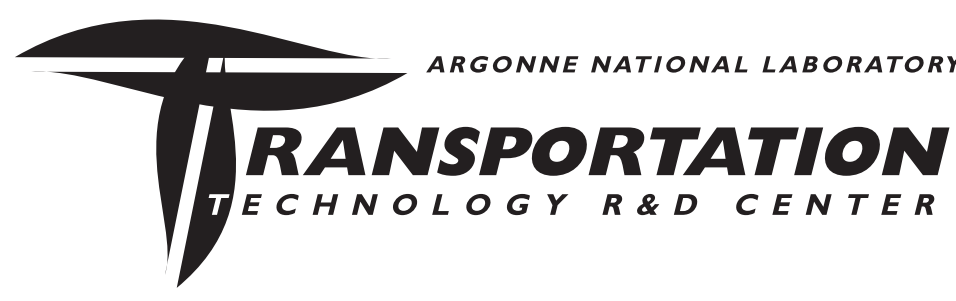

Center for Transportation Research Argonne National Laboratory

Operated by The University of Chicago, under Contract W-31-109-Eng-38, for the

United States Department of Energy 
Argonne National Laboratory, with facilities in the states of Illinois and Idaho, is owned by the United States Government and operated by The University of Chicago under the provisions of a contract with the U.S. Department of Energy.

DISCLAIMER
This report was prepared as an account of work sponsored by an agency of
the United States Government. Neither the United States Government nor
any agency thereof, nor The University of Chicago, nor any of their
employees or officers, makes any warranty, express or implied, or assumes
any legal liability or responsibility for the accuracy, completeness, or
usefulness of any information, apparatus, product, or process disclosed, or
represents that its use would not infringe privately owned rights. Reference
herein to any specific commercial product, process, or service by trade name,
trademark, manufacturer, or otherwise does not necessarily constitute or
imply its endorsement, recommendation, or favoring by the United States
Government or any agency thereof. The views and opinions of document
authors expressed herein do not necessarily state or reflect those of the
United States Government or any agency thereof, Argonne National
Laboratory, or The University of Chicago.

Available electronically at http://www.doe.gov/bridge

Available for a processing fee to U.S. Department of Energy and its contractors, in paper, from:

\author{
U.S. Department of Energy \\ Office of Scientific and Technical Information \\ P.O. Box 62 \\ Oak Ridge, TN 37831-0062 \\ phone: (865) 576-8401 \\ fax: (865) 576-5728 \\ email: reports@adonis.osti.gov
}




\section{The Potential Effect of Future Energy-Efficiency and Emissions-Improving Technologies on Fuel Consumption of Heavy Trucks}

by A. Vyas, C. Saricks, and F. Stodolsky

Center for Transportation Research, Energy Systems Division,

Argonne National Laboratory, 9700 South Cass Avenue, Argonne, Illinois 60439

August 2002

Work sponsored by U.S. Department of Energy

Energy Information Administration

Office of Integrated Analysis and Forecasting

Demand and Integration Division 


\section{NOTICE}

This technical report is a product of Argonne's Energy Systems Division.

For information on the division's scientific and engineering activities, contact:

Director, Energy Systems Division

Argonne National Laboratory

Argonne, Illinois 60439-4815

Telephone (630) 252-3724

Publishing support services were provided by Argonne's Information and Publishing Division (for more information, see IPD's home page: http://www.ipd.anl.gov).

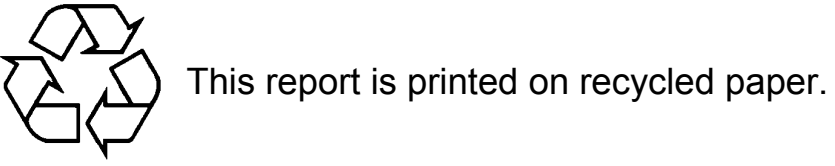





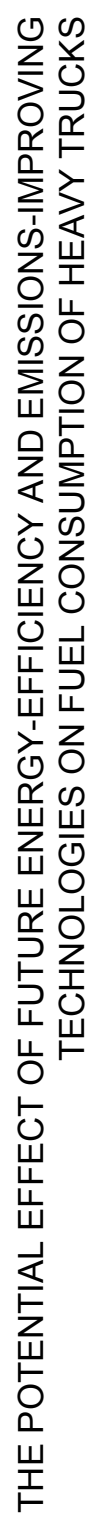

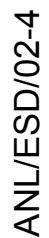




\section{Contents}

Acknowledgments

Abstract.

1 Introduction

2 Technology, Costs, and Market Penetration Potentials of Fuel-Efficiency-Enhancing

Technologies for Medium and Heavy Freight Trucks: Projections to 2025

2.1 Methodology

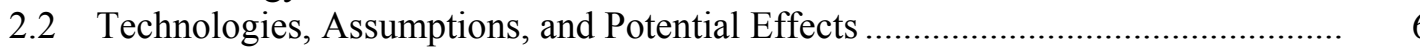

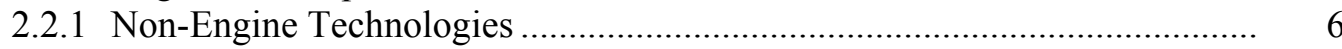

2.2.2 Powertrain Technologies ................................................................... 10

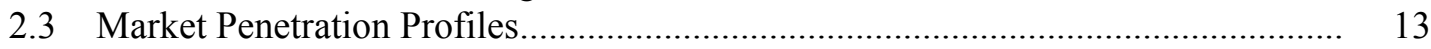

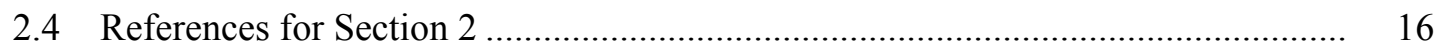

3 Technology, Costs, and Fuel Effects of Meeting 2007 and Later Emission and

Fuel Content Standards for Medium and Heavy Freight Trucks: Projections to 2025 .....

3.1 Current State of Technology

3.1.1 Standards and Test Procedures through 2004 ............................................ 19

3.1.2 Engine/Combustion Controls and Equipment Retrofits ............................. 21

3.1.3 Present and Near-Term Prospective Exhaust Controls................................ 21

3.1.4 Additional Technologies Available Today and in the Near Future .............. 22

3.2 Impact of 2007 and Later Standards ............................................................. 24

3.2.1 Timing of Phase-In for Both Vehicular Emission Limits and

Fuel Properties

3.2.2 Technologies Expected to be Proven/Capable of Commercialization by 2006

3.2.3 Pollutants for Which Final Control Set Remains Undefined or Flexible

3.3 Onboard Fuel Efficiency Effects of 2007 and Later Standards.............................. 26

3.3.1 Speculation on Parasitic Losses............................................................... 26

3.3.2 Decrease in Maximum Potential Engine Efficiency .................................... 34

3.4 Technology Cost Estimates and Credits Other than Efficiency Penalties............... 34

3.5 Emerging Low-Emission Technologies and Their Prospects for

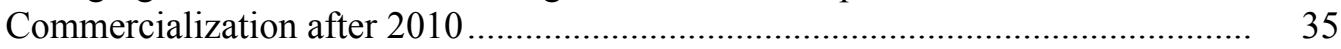

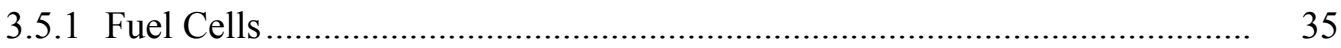

3.5.2 Diesel Electric Hybrids .................................................................... 35 
3.5.3 Effects of Synthetic Diesel Fuel ................................................................ $\quad 35$

3.5.4 The "All Electrically Controlled" Engine................................................ 35

3.6 References to Section 3 ..................................................................... 36

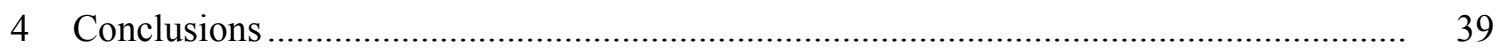

\section{Figures}

1 Market Penetration Profile for Aerodynamics-Improving Technologies for Class 7 and Class 8 Trucks

2 Market Penetration Profile for Fuel-Cell-Operated Auxiliaries for Class 7 and Class 8 Trucks

3 Market-Share-Weighted Fuel Economy Benefits of Aerodynamic Devices - New

4 FTP Transient Cycle

\section{Tables}

1 Class $2 \mathrm{~b}$ and Class 3 Truck Technologies and Their Potential Effects, Cost, and Market Shares.

2 Classes 4-6 Truck Technologies and Their Potential Effects, Cost, and Market Shares.

3 Class 7 and Class 8 Truck Technologies and Their Potential Effects, Cost, and Market Shares. 


\section{Acknowledgments}

The authors thank John Maples and Susan Holte of the Energy Information Administration, U.S. Department of Energy, for their guidance and support. The authors also thank Roy Cuenca of Argonne National Laboratory for his technical advice on fuel-economy-improving technologies. Thanks are due to our technical editor Kevin A. Brown and to Kerri Schroeder, also of Argonne, who provided word processing support. Although many persons helped make this report possible, the authors are solely responsible for its contents. 
$\Delta$ 


\section{Abstract}

Researchers at Argonne National Laboratory analyzed heavy-duty truck technologies to support the Energy Information Administration's long-term energy use projections. Researchers conducted an analysis of several technology options that have potential to improve heavy truck fuel economy and emissions characteristics. The technologies are grouped as fuel-economy-enhancing and emissions-improving. Each technology's potential impact on heavy truck fuel economy has been estimated, as has the cost of implementation. The extent of technology penetration is estimated on the basis of truck data analyses and technical judgment. 
$\Delta$ 


\section{Section 1 Introduction}

The Energy Information Administration (EIA) within the U.S. Department of Energy projects future energy use by various energy consuming sectors. The EIA has developed a modeling tool called the National Energy Modeling System (NEMS) for developing these projections, which are published as the Annual Energy Outlook (AEO). The transportation sector component of NEMS projects energy use by several categories. One of these categories includes heavy-duty trucks. The heavy-duty trucks include all freight-carrying trucks with a gross vehicle weight (GVW) exceeding 8,500 lb. For its projection work for the 2002 AEO, EIA asked Argonne National Laboratory (Argonne) to identify future energy-efficiency and emissionsimproving technologies and their effects on heavy-duty truck fuel economy.

The objective of Argonne's work was to provide the EIA with a set of technologies, associated impacts on fuel economy, and potential market penetration for each technology. Two sets of technologies, one aimed at enhancing fuel economy and the other aimed at enhancing emissions characteristics, were evaluated. This report summarizes the methodology used and estimated impacts of these technologies on truck fuel economy. 
$\Delta$ 


\section{Section 2 \\ Technology, Costs, and Market Penetration Potentials of Fuel-Efficiency-Enhancing Technologies for Medium and Heavy Freight Trucks: Projections to 2025}

This section describes the methodology used in identifying promising technologies, their potential impacts, and their market penetration potentials.

\subsection{Methodology}

The project team developed information from various sources to identify truck technologies that are most likely to be introduced during the next two decades. A few of the technologies included in the analysis represent research sponsored by the U.S. Department of Energy (DOE). The technologies were in two groups: those affecting the powertrain and those affecting nonengine loads. The Technology Roadmap for the $21^{\text {st }}$ Century Truck Program, prepared by the U.S. Department of Energy, Office of Heavy Vehicles Technology (OHVT), was used in estimating the potential energy savings of various technologies (DOE 2000). Several other publications were used to obtain information about technologies and their impacts on fuel economy.

Projecting the market penetration of new technology is normally done by applying one or more models to predict market share. The EIA uses a vehicle choice model for projecting market penetration by new technologies and alternative fuels in the light-duty sector. Projections from this model are based on data collected through consumer preference surveys. A similar model was not available for the heavy-duty sector. The light-duty vehicle selection is highly affected by such behavioral variables as perceived image of owning a given vehicle, while the heavy-duty vehicle selection is affected by intended use, cost, and benefits. Some simple payback models exist that evaluate incremental cost of a technology and estimated fuel savings. Since the future year fuel prices were not available during this analysis, an approach based on technical judgment was employed, although it is acknowledged that pressures imposed by fuel price and perhaps future petroleum supply security concerns will be important accelerants to the promulgation of these technologies. Thus, our projections reflect less than what would be "maximum feasible" penetration for any forecast year, given manufacturing and supply constraints.

Each technology's potential fuel savings was evaluated against its cost. Further, the potential maximum market penetration was then evaluated in terms of segments of trucks that may obtain the maximum benefits. An introduction year was selected on the basis of a technology's status of development, and a time interval for reaching the maximum market penetration was assigned. With an estimated market introduction date and maximum market penetration, a demand curve was plotted that shows sales of the new technology over time. There are two regimes in the market penetration curve: (1) initial penetration, where the market is constrained by manufacturing capability and lack of consumer awareness, and (2) mature market, where supply quickly responds to demand. We characterized two cases: a medium-technology case (by 
considering relatively low-cost and less-innovation-dependent technologies) and a hightechnology case by including higher-cost and more-innovation-dependent technologies.

Argonne performed a literature search on advanced truck technologies for estimating the future fuel economy of three groups of trucks: light medium (GVW classes 2B and 3), heavy medium (GVW classes 4-6), and heavy-duty (GVW classes 7 and 8). The most reliable data were the potential fuel economy of the advanced class 8 tractor-trailer and the advanced class $2 \mathrm{~B}-6$ medium-duty hybrid truck, which are subjects of detailed studies (Stodolsky et al. 1998; An et al. 1999; DOE 2000; Englar 2001). The least-reliable data were the future costs of all technologies. For the less-reliable data, we relied on the collective judgment of several Argonne researchers. Both retrofit and replacement technologies were assessed. Much of the cost information had to be estimated by using the costs of typical current production technologies because the advanced technologies do not yet exist in production. In a few cases, DOE cost goals were used.

The impacts on fuel economy were determined by grouping the technology as either one that reduces non-engine or parasitic losses (those that affect the energy needed to propel the vehicle - e.g., rolling resistance, aerodynamic drag, and auxiliary load) or one that reduces engine losses (e.g., improved lubrication, increased peak cylinder pressure, and improved thermal management). The introduction year also depended, in part, on the schedule of upcoming emission standards. In model year 2004, emission standards are scheduled to be tightened significantly (EPA 1997), which requires many new technologies (Browning 1997). While many emissions control technologies (like exhaust aftertreatment) will reduce fuel economy, some will actually improve fuel economy (like higher fuel injection pressure). Market penetration curves were developed for each technology on the basis of earlier Argonne work (Mintz and Vyas 1991; Teotia et al. 1999 and 2001). These curves also characterized market penetration of new technologies constrained by manufacturing capacity and lack of consumer awareness.

As a check, we calculated the improvement in fuel economy of a Class 8 tractor-trailer on the basis of our estimates. Under the assumption that a set of major technologies is adopted, the fuel economy of the truck rises from a baseline value of $6.2 \mathrm{mpg}$ (for new trucks in VIUS 2000) to $10.1 \mathrm{mpg}$. This mileage is consistent with an industry goal of a 10-mpg truck, as described by Merrion (1994) and adopted by DOE (DOE 1997 and 2000).

\subsection{Technologies, Assumptions, and Potential Effects}

Various technologies that were evaluated, key assumptions, and estimated potential effect on fuel economy of heavy trucks are described in this section.

\subsubsection{Non-Engine Technologies}

The non-engine technologies reduce a vehicle's parasitic losses. The potential improvement in fuel economy of such technologies was developed primarily from earlier studies (Mintz and Vyas 1991; Stodolsky et al. 1999; DOE 2000, and Englar 2001) and adjusted to match the average speed of a truck duty-cycle (a more comprehensive study would model each use within the truck classes to estimate the detailed impact of duty cycle on fuel economy). The improved non-engine technologies are classified in four broad groups: (1) those reducing aerodynamic drag, 
(2) those reducing rolling resistance, (3) those affecting better management of auxiliaries, and

(4) those reducing empty vehicle mass. In most of the cases, several technologies were identified within each group.

Aerodynamic Drag. The effects of reducing aerodynamic drag are a strong function of vehicle speed because the power needed to overcome aerodynamic drag varies as the cube of speed. Heavy-duty trucks classed as long-haul travel mostly at highway speeds (65 mph), while medium-duty trucks travel mostly at lower speeds (approximately $45 \mathrm{mph}$ is the maximum speed observed in WVU's suburban driving schedule by Clark et al.). Therefore, the benefits of reduced aerodynamic drag are significant for most heavy-duty trucks. ${ }^{1}$ We assume some advanced dragreduction treatments can be retrofitted onto the existing fleet. The aerodynamic forces are estimated to require $21.3 \%$ of the energy used by a class 8 truck at $65 \mathrm{mph}$ steady speed (DOE 2000). The Government-Industry Research Partnership under the 21 st Century Truck Program proposes a $20 \%$ reduction in aerodynamic energy usage, which is equivalent to a $4.5 \%$ improvement in fuel economy. We have also included a new DOE-sponsored technology under the high-technology case - pneumatic blowing - that is expected to further reduce aerodynamic drag. The technology involves pressurized air blowing through selected points on the exterior surface of a truck. The technology has already been applied to reduce aircraft drag and increase stability. The technology is claimed to have the potential to save energy, even after deducting energy expended for the generation of pressurized air (Englar 2001).

For class 7 and class 8 heavy trucks, four technologies were identified for reducing aerodynamic drag:

1. Cab top deflectors, sloping hood, and cab side flares;

2. Closure or coverage of the gap between tractor and trailer, aerodynamic bumper, underside air baffles, and wheel well covers;

3. Trailer leading and trailing edge curvatures; and

4. Pneumatic blowing.

The first technology involving cab top deflectors is on the market and can be retrofitted to existing trucks.

For class 8 heavy-duty trucks, we assume that drag-reduction technologies would improve fuel economy by $10.8 \%$ (Englar 2001; Stodolsky et al. 1999); for heavier medium trucks (classes 4-6), we assume that they would improve fuel economy by $7.5 \%$; and for lighter medium-duty trucks (classes $2 \mathrm{~B}$ and 3 ), we assume that they would improve fuel economy by $2.5 \%$. We assume that the costs of drag reduction vary substantially for heavy trucks. With a pneumatic blowing system, the cost could be as high as $\$ 5,250$. In terms of development, the pneumatic blowing system is at the laboratory stage; further research may help to lower the initial

\footnotetext{
${ }^{1}$ The clear exception in this class is refuse haulers and concrete mixers, which travel at very low average speeds. A more complete study would differentiate among uses within the heavy-duty truck class.
} 
cost of this technology. The cost for the heavier medium trucks would be $\$ 1,950$ for the maximum benefits; for the lighter medium trucks, the cost would be proportionately lower at $\$ 600$.

Rolling Resistance. Three rolling-resistance-reducing technologies were identified for the class 8 heavy trucks:

1. Low-resistance tires,

2. Super single tires, and

3. Pneumatic blowing to provide some lift and thereby reduce rolling resistance.

The first two technologies are mutually exclusive. The share of energy required to overcome rolling resistance is estimated as $12.8 \%$ for the class 8 trucks (DOE 2000). The joint GovernmentIndustry Research Partnership under the $21^{\text {st }}$ Century Truck Program proposes a $40 \%$ reduction in rolling resistance energy, which is equivalent to a $5.4 \%$ increase in fuel economy.

Energy expended in overcoming rolling resistance is directly proportional to speed and mass, implying that the fuel economy of heavier trucks that travel at high speeds can benefit significantly from reductions in this resistance. Low-resistance tires have been on the market for some time, but some types require higher inflation pressure and frequent monitoring. These requirements may have limited the extent of their penetration. The low-resistance tires can be used by the existing class 8 trucks and are estimated to improve fuel economy by $3 \%$. The super single tires can be used only in new class 8 trucks and are estimated to improve fuel economy by about 2-3\% (Stodolsky et al. 1999; DOE 1997). We assume a 3\% improvement with super singles. For both groups of medium trucks, we assumed only one technology - the lowresistance tires - that would improve fuel economy by $2.5 \%$. We assume an incremental cost of \$15-20 per low-resistance tire for the heavy-duty trucks, with 18 tires replaced every 60,000 miles; we also assume that 10 tires are replaced for the heavier medium-duty trucks and six tires are replaced on lighter medium-duty trucks every 50,000 miles. The super singles are considered only for the heavy-duty trucks, with eight super singles at an incremental cost of \$30-40 for 16 regular tires, replaced every 60,000 miles (Bridgestone 1996).

The use of pneumatic blowing to provide a slight lift to the trailing axles is being researched (Englar 2001). The technology has a potential to increase fuel economy by more than the assumed $1.2 \%$ in this analysis. Safety and road dust issues associated with this technology have not yet been researched. We assigned the technology a low $1.2 \%$ fuel economy gain, assuming that it would not be deployed $100 \%$ of the time. A cost of $\$ 500$ - in addition to the cost of $\$ 2,500$ assigned to pneumatic blowing for reducing aerodynamic drag - was assigned for pipes, jets, valves, and additional controls. 
Accessory Load. The heavy and medium trucks have several auxiliaries operated through their engines:

- Air compressor,

- Hydraulic pumps,

- Coolant pump,

- Engine oil and fuel pumps,

- Fans, and

- Air conditioning compressor.

Since most of these auxiliaries operate all the time while engine is turned on (even when not needed), they consume some energy. The engine also runs the alternator that provides electric power for lighting, windows, mirror adjustment, heating, audio entertainment devices, and cab comforts. Many class 8 trucks are being equipped with an on-board personal computer, an Internet connection through the cab top dish antenna, a refrigerator, a microwave oven, a coffee maker, and video entertainment devices.

Two alternative (mutually exclusive) technologies for reducing accessory load were considered: (1) electric auxiliaries and (2) fuel-cell-operated auxiliaries. The first option of having electrically operated auxiliaries is expected to increase the fuel economy of heavy-duty trucks by $1.5 \%$ at an additional cost of $\$ 500$. For medium trucks, this option was treated as a part of engine technologies as either an integrated starter-alternator or a hybrid powertrain. The second alternative of fuel-cell-operated auxiliaries included in the high-technology case was considered feasible for heavy-duty trucks only because it would not be cost-effective for medium trucks. DOE is sponsoring research on fuel cell technology with cost goals of $\$ 30-35 / \mathrm{kW}$. The target is to have the technology introduced by 2010. Also, all major vehicle manufacturers have their own fuel cell programs. We assumed that fuel-cell-operated auxiliaries would be ready for introduction by 2012. We also assumed that the original equipment manufacturers would install small $(\sim 5 \mathrm{~kW})$ fuel cell units, thereby reducing cost. Currently, a few small diesel-engineoperated power units are available, but because they are offered as an add-on, their per-kW cost is much higher than what truck engine manufacturers could achieve. The technology is expected to increase fuel economy by $6 \%$ at an additional cost of $\$ 1,500$. Aside from continuous operation during long distance driving, the heavy-duty truck engines are often kept idling during rest stops (Stodolsky et al. 2000). The use of fuel-cell-operated accessories has potential to reduce such idling and further improve the overall fuel economy of heavy-duty trucks.

Vehicle Mass. Lightweight materials allow weight-limited trucks to increase carrying capacity (thereby reducing the number of trucks for a given tonnage of freight hauled) and allow improvements in fuel economy for those trucks that "cube out" (i.e., are volume limited). We assume that an unloaded tractor-trailer weighs $26,000 \mathrm{lb}$ and that the use of aluminum, plastics, and other high-strength, lightweight materials reduces the weight by 4,500-9,000 lb. Assuming 
that a loaded cubed-out tractor-trailer weighs $60,000 \mathrm{lb}$, the use of lightweight materials would reduce the loaded truck mass by $7.5-15 \%$.

Argonne has attempted to simulate the effect of mass reduction on the fuel economy of heavy trucks through the National Renewable Energy Laboratory's Advanced Vehicle Simulator Model, ADVISOR (Wipke et al. 1998 and 1999). Because there are no established driving schedules for heavy trucks, the Argonne simulations relied on a few driving schedules developed by the West Virginia University (WVU) that are included in ADVISOR (Clark et al. 1999). While simulating a class 8 truck on WVU Intercity Driving Schedule, a fuel economy gain of $0.6 \%$ was observed for each $1 \%$ mass reduction from $65,000 \mathrm{lb}$ to $58,000 \mathrm{lb}$. The maximum speed during the simulation was $61 \mathrm{mph}$, and the average running speed (excluding stops) was 37.5 mph. Most intercity class 8 trucks average a much higher speed than $37.5 \mathrm{mph}$. The gain in fuel economy due to mass reduction could be higher than $0.6 \%$ at higher average speeds. We assumed a $0.66 \%$ increase in fuel economy for each $1 \%$ weight reduction and estimated fuel economy increases as $5-10 \%$. While simulating a class 6 truck on a WVU Suburban Driving Schedule, a fuel economy gain of $0.48 \%$ was observed for each $1 \%$ mass reduction from $22,600 \mathrm{lb}$ to 21,800 lb. The maximum speed during the simulation was $44.8 \mathrm{mph}$, and the average running speed was $21.5 \mathrm{mph}$. The potential fuel economy gains for medium trucks, both heavy- and light-, were capped at 5\% since they are less likely to be weight- or volume-limited, and so the use of expensive lightweight material would not be cost-effective.

\subsubsection{Powertrain Technologies}

Powertrain technologies increase the efficiency of the engine and transmission, thereby increasing the overall fuel economy. These technologies are synergistic and their effects are multiplicative, as compared with non-engine technologies, the effects of which are additive. Three groups of powertrain technologies were included:

1. Those improving transmission efficiency,

2. Those improving diesel-engine-based powertrain efficiency, and

3. Those improving gasoline-engine-based powertrain efficiency.

Transmission. High-efficiency transmission technologies are aimed at reducing mechanical losses in these components by 25-30\% (DOE 1997; 2000), resulting in an improvement in fuel economy of about 1-3\% (Stodolsky et al. 1999; DOE 1997). Actual efficiency improvements are a function of duty cycle, with a higher efficiency improvement possible during congested driving (An et al. 1999). The $21^{\text {st }}$ Century Truck Program estimates a $2.3 \%$ energy use by transmission at $65 \mathrm{mph}$ steady speed and proposes a $30 \%$ reduction, which is equivalent to a $0.7 \%$ gain in fuel economy. The energy use would be much greater in city driving; consequently, we assume a higher gain of $2 \%$ in all truck classes due to improvements in the transmission and in its lubricants (Ehlbeck et al. 1991).

Diesel Engine. This category is applicable to all diesel-engine trucks with differing technology menus for class 7 and class 8 heavy-duty trucks and class 2B-6 medium trucks. 
According to the 1997 Vehicle Inventory and Use Survey (VIUS), heavy-duty (classes 7-8) trucks use $69 \%$ of all fuel used by heavy trucks, heavier medium (classes 4-6) trucks use 14\%, and lighter medium (classes 2B-3) trucks use 17\% (VIUS 2000). Also - according to the 1997 VIUS - $98 \%$ of the new heavy-duty (classes $7-8$ ) trucks, nearly $68 \%$ of the new classes $4-6$ (heavier medium) trucks, and slightly more than $2 \%$ of the new class $2 \mathrm{~B}-3$ (lighter medium) trucks have diesel engines. The joint Government-Industry Research Partnership under the $21^{\text {st }}$ Century Truck Program estimates the energy losses within a diesel engine to be $60 \%$ (DOE 2000). Although these losses seem very high, the diesel engine is the most efficient of all internal combustion engines. Homogeneous charge compression-ignition (HCCI) combustion is the subject of some proposed research. HCCI is a cross between spark-ignition and compressionignition (diesel) combustion, whereby well-mixed air and fuel are ignited. Combustion occurs spontaneously and homogeneously without flame propagation. Because of the very lean charge, local flame temperature is low, thereby drastically lowering $\mathrm{NO}_{\mathrm{x}}$ emissions. Because the HCCI concept is at a research program evaluation stage, we did not explore the impacts of HCCI engines. Once some progress is made and preliminary results are available, we recommend that the impacts of this technology be assessed in future studies of truck fuel economy and emissions.

Four diesel engine technologies were identified for heavy-duty (classes 7-8) trucks:

1. Internal friction reduction,

2. Increased peak cylinder pressure,

3. Improved fuel injection and more efficient combustion, and

4. Reduced waste heat and improved thermal management.

Reducing internal friction is estimated to improve the fuel economy of heavy-duty trucks by $2 \%$ and increase peak cylinder pressure by 4\% (DOE 2000). Improved fuel injection encompasses such technologies as electronic fuel injection (e.g., electronic unit injectors and common rail injectors), electronic unit pump and electronic distributor pump systems (Browning 1997), and other technologies that would be developed with a better understanding of diesel spray (ANL 2000). Gains in fuel economy are estimated as 6\% (DOE 2000). DOE is supporting research on reducing waste heat and improving thermal management. More efficient turbochargers and turbocompounding are among various options under this technology group. The technology is projected to improve heavy-duty truck fuel economy by $10 \%$. Incremental costs for the four technology groups are estimated at $\$ 500, \$ 1,000, \$ 1,500$, and $\$ 2,000$, respectively.

Four diesel engine technologies were also identified for medium trucks:

1. Turbocharging and direct injection;

2. Integrated starter alternator with idle off and limited regenerative braking capability; 
3. Lower internal friction, improved fuel injection, and more efficient combustion; and

4. Hybrid electric powertrain.

Because heavier (classes 4-6) medium trucks and lighter (classes 2B-3) medium trucks are used differently, improvements in fuel economy were projected to be lower for the lighter trucks. The lighter trucks are less likely to carry loads, but they are used more for services by farmers, utilities, craftsmen, construction contractors, and delivery companies (VIUS 2000).

Turbocharging and direct injection are estimated to improve the fuel economy of heavier medium trucks by $8 \%$ and of lighter medium trucks by $5 \%$ at a cost of $\$ 1,000$ and $\$ 700$, respectively.

The integrated starter-alternator technology would enable electrical operation of such auxiliaries as fuel, coolant, vacuum, and hydraulic pumps. The technology would also reduce the amount of engine idling at traffic lights and in congested traffic and provide limited regenerative braking capability. The technology is estimated to improve fuel economies of both subgroups by $5 \%$ at a cost of $\$ 1,200$. Through lower internal friction, improved fuel injection, and more efficient combustion, the fuel economy of medium trucks is estimated to improve by $8 \%$ at a cost $\$ 2,000$.

A hybrid electric powertrain with associated engine power reduction improves the fuel economy of a car substantially (in the range of 21-200\%), particularly in congested driving (An et al. 2001; Santini et al. 2002). When the gains not directly associated with the hybrid powertrain are subtracted, the estimated range of fuel economy gain is $21-96 \%$. Hybrid electric cars cost $\$ 3,000-5,000$ more than similar models equipped with conventional engines (CarPoint 2001). Hybrid electric powertrains are projected to improve the fuel economy of medium trucks by 40 $71 \%$ (An et al. 2000; DOE 2000). We estimate a $40 \%$ improvement at a cost of $\$ 6,000-\$ 8,000$.

Gasoline Engines. Most of the heavy-duty (classes 7-8) new trucks are equipped with diesel engines (VIUS 2000), and, consequently, no gasoline engine technologies were characterized for them. Four technology groups were characterized for medium truck gasoline engines:

1. Electronic fuel injection, double overhead cams, and multiple valves;

2. Integrated starter alternator with idle off and limited regenerative braking capability;

3. Direct fuel injection; and

4. Hybrid electric powertrain.

Use of electronic fuel injection is common in light-duty gasoline engines. Its use would become more prevalent in medium trucks because of the more stringent emissions standards (Browning 1997). Double overhead cams and multiple valves have increased engine specific power and, thereby, reduced the specific fuel consumption in cars. Although the average fuel economy of cars has not improved over the last 15 years because of demand for better 
performance, these technologies have potential to improve the fuel economy of gasoline-powered trucks, which, in commercial service, are more sensitive to fuel cost. These technologies are estimated to increase the fuel economy of medium trucks by $5 \%$ at a cost of $\$ 700-1,000$. As in the case of diesel engines, the integrated starter-alternator technology would enable the use of electric accessories, reduce the amount of idling at traffic lights and in congested driving, and provide limited regenerative braking capability. The technology is estimated to improve medium truck fuel economy by $5 \%$ at a cost of $\$ 1,000-1,200$.

The gasoline direct injection (GDI) (also referred to as spark-ignition direct-injection SIDI) technology has potential to improve gasoline engine fuel economy by $22-24 \%$ (Cole et al. 1998 and 1999). However, it is unlikely to meet the emissions standards without emissions control equipment that require frequent regeneration. When fuel consumption for regeneration is accounted for, the gain in the fuel economy is estimated to be $8-10 \%$ (Stovell et al. 1999). The $14 \%$ fuel economy penalty for regeneration was estimated in laboratory experiments and potentially can be reduced to $10 \%$ or less. We estimated a $12 \%$ gain in fuel economy for this technology at a cost of $\$ 700-1,000$.

As discussed above, the hybrid powertrain technology is expected to improve fuel economy by about 40-70\% (An et al. 1999; DOE 2000). We estimate a $45 \%$ improvement in fuel economy at a cost of $\$ 6,000-8,000$. The estimated improvement in fuel economy for the hybrid technology is higher for the gasoline-powered medium trucks because they usually have lower laden weight and fewer annual miles, indicating that they are used in congested conditions (VIUS 2000).

\subsection{Market Penetration Profiles}

A new technology entering the market would compete with an existing technology, and its market share would depend on the benefits (or utility) it provides and cost/penalties (or disutility) it imposes. A new technology's extent of penetration is usually limited during the introductory period because only a small fraction of the buyers adopt it. When others learn from these early buyers and production-related issues are resolved, its rate of market penetration would rise. The rate of market penetration would eventually slow down when a large majority of buyers that benefit from the technology have adopted it. The market penetration over time would follow a classical S-shaped curve. Researchers and marketing professionals have investigated new technology market penetration and substitution and have developed mathematical models for projecting such market penetration pattern for new technologies (Mansfield 1961; Blackman 1974; Paul 1979; Bass 1980; Teotia and Raju 1986).

Our data for each technology included possible year of introduction, maximum market penetration, and estimated period for achieving the maximum market penetration. To develop market penetration profiles for the truck technologies listed in Tables 1-3 in Section 3, we adapted a logit function formulation in which function $F\{t\}$ defines the market share of a new technology at time $t$. The old technology share, if any, would be $1-F\{t\}$. We selected the following functional form, which uses two parameters, $\delta$ and $\beta$, to determine the shape of the curve (Santini 1989):

$$
t=\delta+\beta \ln [F\{t\} /(1-F\{t\})]+\mu .
$$


Here, $\delta$ and $\beta$ are coefficients that determine the shape of the market penetration curve, and $\mu$ is the error term. The term $\delta$ defines the midpoint in time for the symmetric market penetration curve represented by the above equation, while $\beta$ determines the rate at which the new technology would penetrate the market. We selected values of $\delta$ and $\beta$ to reflect the potential maximum penetration and when it was likely to happen. Figures 1 and 2 show market penetration curves for two representative technologies.

Each technology's potential of increasing fuel economy of various trucks is shown in Tables 1-3 in Section 3. Collectively, these technologies can improve truck fuel economy substantially. However, their impact on the on-road truck fleet and overall new truck fuel economy will be different at different points in time. For example, four aerodynamic-improving technologies for class 8 heavy trucks are listed in Table 3. These four technologies differ in introduction year, fuel economy benefit, and maximum penetration. Their market penetration profiles also differ significantly. Consequently, the market-share-weighted combined benefits of the technologies would be different at different points in time. Figure 3 shows the market-shareweighted benefits of these aerodynamic-improving technologies on new-truck fuel economy.

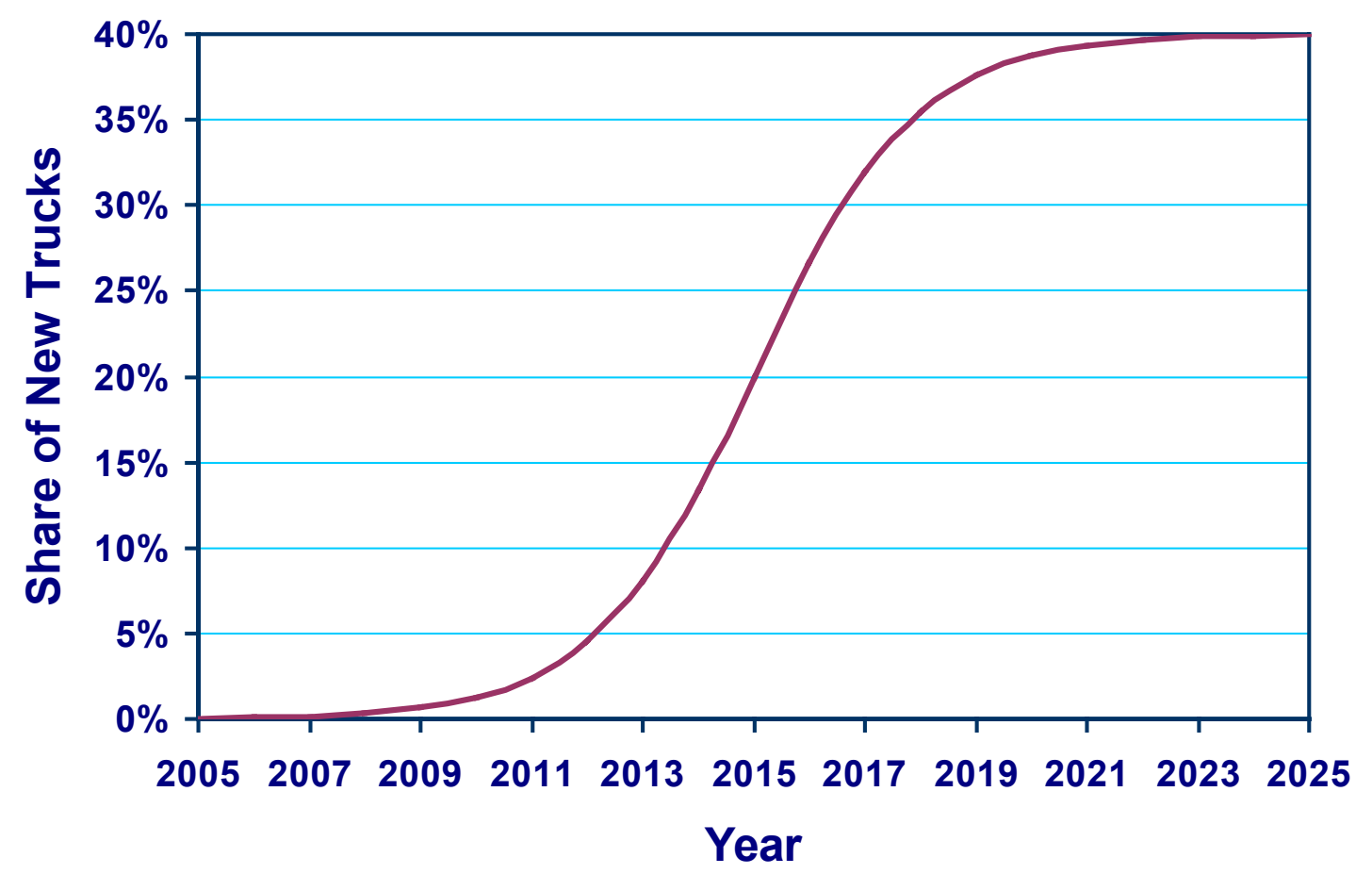

Figure 1 Market Penetration Profile for Aerodynamics-Improving Technologies for Class 7 and Class 8 Trucks (closing/covering gap between tractor and trailer, aerodynamic bumper, underside baffles, and wheel well covers) 


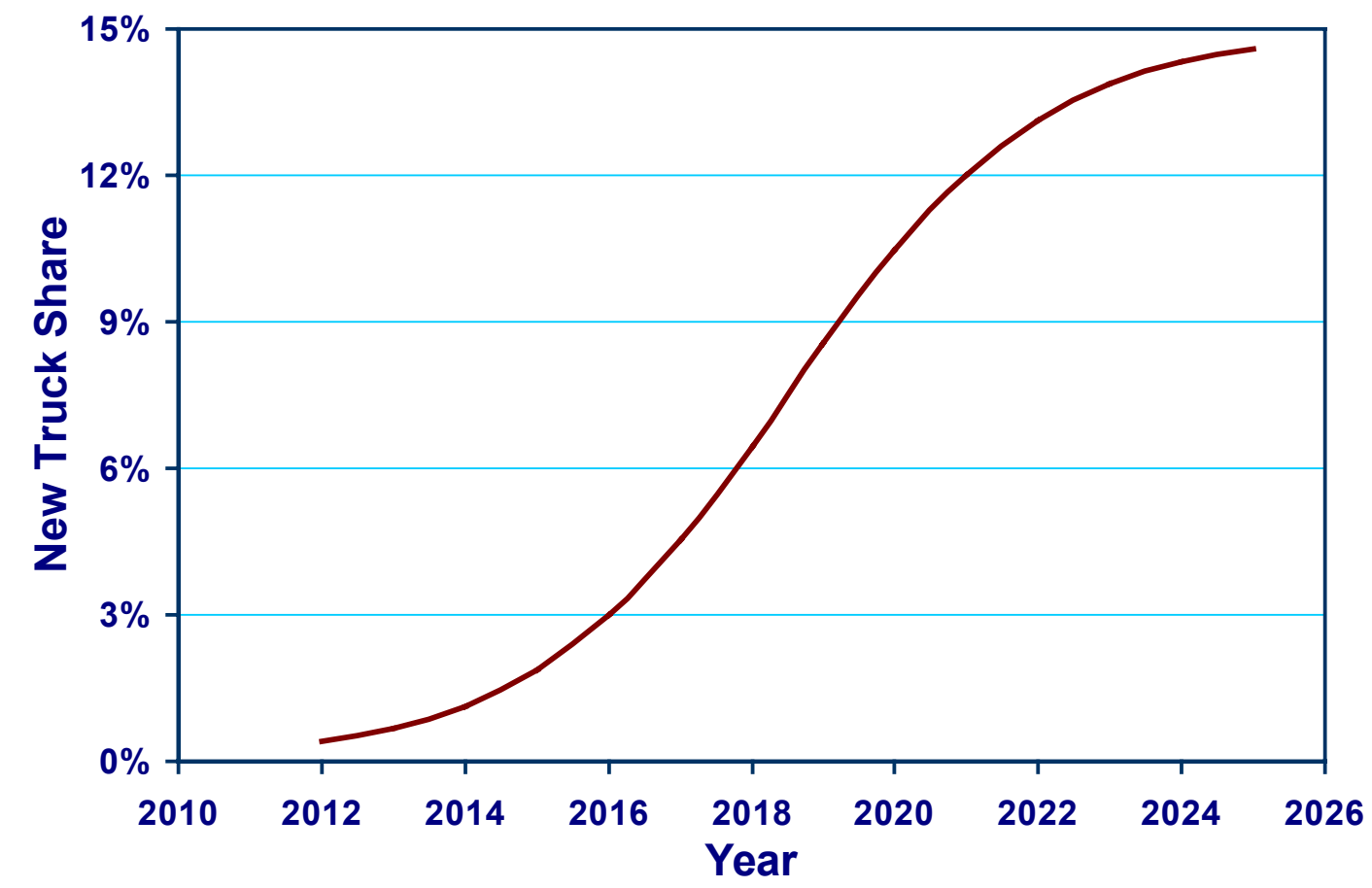

Figure 2 Market Penetration Profile for Fuel-Cell-Operated Auxiliaries for Class 7 and Class 8 Trucks

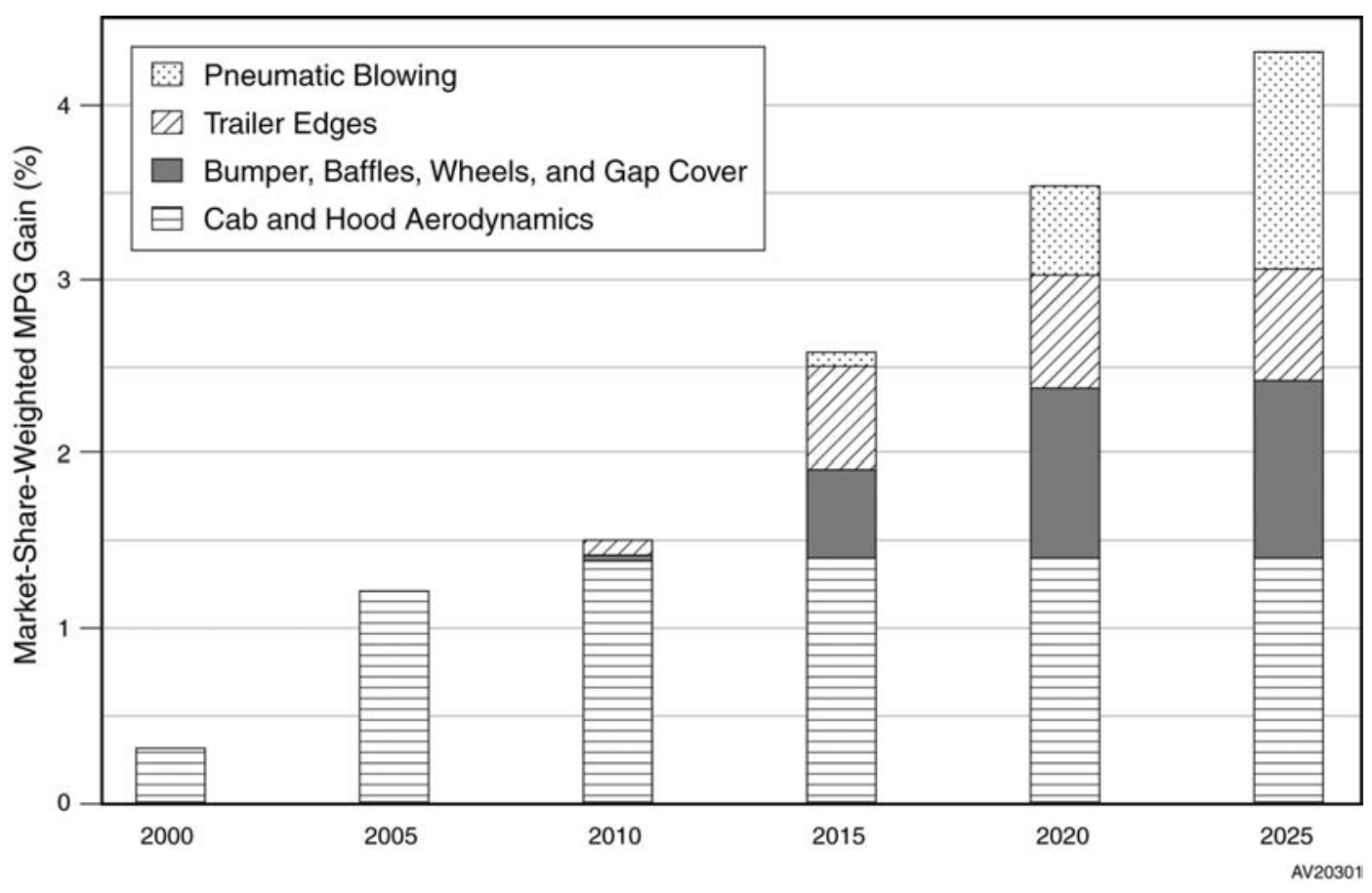

Figure 3 Market-Share-Weighted Fuel Economy Benefits of Aerodynamic Devices - New Class 7 and Class 8 Trucks 


\subsection{References for Section 2}

An, F., et al., 2001, "Evaluating Commercial and Prototype HEVs," presented at SAE

International, 2001 Annual Congress and Exposition, paper 2001-01-0951, Warrendale, Pa.

An, F., et al., 2000, "Scenario Analysis of Hybrid Class 3-7 Heavy Vehicles," presented at SAE International, 2000 Annual Congress and Exposition, paper 2000-01-0989, Warrendale, Pa.

An, F., et al. 1999, "Fuel and Emissions Impacts of Heavy Hybrid Vehicles," presented at the ISATA, paper no. 99CPE015, Vienna, Austria, June.

ANL: Argonne National Laboratory

ANL, 2000, "X-Ray Vision: Taking a Hard Look at Fuel Sprays and Combustion," TransForum 3:1, Argonne, Ill.

Bass, F.M., 1980, "The Relationship Between Diffusion Rates, Experience Curves, and Demand Elasticities for Consumer Durable Technological Innovations," Journal of Business 53(3):s51s67.

Blackman, A.W., 1974, "The Market Dynamics of Technological Substitutions," Technological Forecasting and Social Change 6:41-63.

Bridgestone, 1996, "Bridgestone Tire Price and Data Book," Bridgestone Technical Publications, Nashville, Tenn.

Browning, R., 1997, “Technologies and Costs for On-Road Heavy-Duty Engines Meeting 2004 Emissions Standards," Society of Automotive Engineers Technical paper no. 973256, Society of Automotive Engineers, Warrendale, Pa.

CarPoint 2001, "MSRP Data on Toyota Prius and Corolla," at http://carpoint.msn.com/Vip/Overview/Toyota/Prius/New.asp and http:/carpoint.msn.com/Vip/Overview/Toyota/Corolla/New.asp

Clark, N.N., et al., 1999, "Application of the New City-Suburban Heavy Vehicle Route (CSHVR) to Truck Emissions Characterization," in Special Publication SP-1459, Topics in General Emissions, pp. 1-15, paper 1999-01-1467, SAE International, Warrendale, Pa.

Cole, R.L., R.B. Poola, and R. Sekar, 1999, Emissions and Fuel Economy of a Vehicle with a Spark-Ignition, Direct-Injection Engine: Mitsubishi Legnum GDI, Argonne National Laboratory report ANL/ESD-TM-149, Argonne, Ill.

Cole, R.L., R.B. Poola, and R. Sekar, 1998, "Exhaust Emissions of a Vehicle with a DirectInjection Engine," pp. 67-77 in Direct Injection: Engines, Emissions, and Aftertreatment, SAE International Report SP-1399, Warrendale, Pa.

DOE: U.S. Department of Energy 
DOE, 1994, Assessment of Costs and Benefits of Flexible and Alternative Fuel Use in the U.S. Transportation Sector, Technical Report Fourteen: The Potential of Alternative Fuels in Nonroad Vehicles to Reduce Reliance on Imported Energy Sources, U.S. Department of Energy, Office of Policy, unpublished.

DOE, 1997, OHVT Technology Roadmap, U.S. Department of Energy, Office of Heavy Vehicle Technologies, report DOE/OSTI-11690 (DE98001287), Washington, D.C., Oct.

DOE, 2000, Technology Roadmap for the $21^{\text {st }}$ Century Truck Program: A Government-Industry Research Partnership, U.S. Department of Energy, Office of Heavy Vehicles Technologies, report 21CT-001, Washington, D.C.

Ehlbeck, J.M., and M. von Mayenburg, 1991, "Increasing Heavy-Duty Truck Fuel Economy," in the Transactions of the SAE, SAE paper no. 912662, SAE International, Warrendale, Pa.

Englar, R.J., 2001, "Advanced Aerodynamic Devices to Improve the Performance, Economics, Handling, and Safety of Heavy Vehicles," SAE International Annual Congress and Exposition, paper 2001-01-2072, Warrendale, Pa.

EPA: U.S. Environmental Protection Agency

EPA, 1997, Emission Standards Reference Guide for Heavy-Duty and Nonroad Engines, U.S. Environmental Protection Agency, Office of Air and Radiation, publication no. EPA420-F97-014, Washington, D.C., Sept.

Mansfield, E., 1961, “Technical Change and Rate of Imitation," Econometrica 29:741-765.

Merrion, S., 1994, "Diesel Engine Design for the 1990s," Fortieth L. Ray Buckendale Lecture, Society of Automotive Engineers publication SP-1011, Society of Automotive Engineers, Warrendale, Pa.

Mintz, M., and A. Vyas, 1991, Forecast of Transportation Energy Demand through the Year 2010, Argonne National Laboratory report ANL/ESD-9, Argonne, Ill.

Paul, R.A., 1979, The Impact of Future Diesel Emissions on the Air Quality of Large Cities, U.S. Environmental Protection Agency Report EPA-45075-79-005, Research Triangle Park, N.C.

Santini, D.J., 1989, “Interactions among Transportation Fuel Substitution, Vehicle Quantity Growth, and National Economic Growth," Transportation Research Part A 23(3):183-207.

Santini, D.J., et al., 2002, "Hybridizing with Engine Power Reduction," Transportation Research Board, Eighty-First Annual Meeting, paper 02-4095, Washington, D.C.

Stodolsky, F., L. Gaines, and A. Vyas, 2000, Analysis of Technology Options to Reduce the Fuel Consumption of Idling Trucks, Argonne National Laboratory report ANL/ESD-43, Argonne, Ill. 
Stodolsky, F., A. Vyas, and R. Cuenca, 1999, unpublished information, Argonne National Laboratory, Argonne, Ill.

Stodolsky, F., et al., 1998, "Lifecycle Analysis for Freight Transport," presented at the Total Life Cycle Conference and Exposition, Society of Automotive Engineers Technical Paper no. 982206, Graz, Austria, Dec.

Stovell, C., et al., 1999, "Emissions and Fuel Economy of 1998 Toyota with a Direct Injection Spark Ignition Engine,” SAE International Paper no. 1999-01-1527, Warrendale, Pa.

Teotia, A.P., et al., 2001, Macroeconomic Impacts of Clean Diesel Engines, Phase 2 Report: U.S.-Produced Clean Diesel Engines and SIDI Gasoline Engines for Selected Light Trucks, Argonne National Laboratory report ANL/ESD/TM-164, Argonne, Ill.

Teotia, A.P., et al., 1999, Assessing Economic Impacts of Clean Diesel Engines, Phase 1 Report: U.S.- or Foreign-Produced Clean Diesel Engines for Selected Light Trucks, Argonne National Laboratory report ANL/ESD/TM-155, Argonne, Ill.

Teotia, A.P.S., and P.S. Raju, 1986, "Forecasting the Market Penetration of New Technologies Using a Combination of Economic Cost and Diffusion Models," Journal of Product Innovation and Management 4:225-237.

VIUS, 2000, 1997 Vehicle Inventory and Use Survey: Micro Data Compact Disk and Documentation, Bureau of the Census, Washington, D.C.

Wipke, K., M. Cuddy, and S. Bunch, 1999, “ADVISOR 2.1: A User-Friendly Advanced Powertrain Simulator Using a Combined Backward/Forward Approach," in IEEE Transactions on Vehicular Technology, Special Issue on Hybrid and Electric Vehicles, Columbus, Ohio.

Wipke, K., et al., 1998, “ADVISOR 2.0: A Second-Generation Advanced Vehicle Simulator for Systems Analysis," Proceedings of North American EV and Infrastructure Conference and Exposition, Phoenix, Ariz., Dec. 3-4. 
Section 3

\section{Technology, Costs, and Fuel Effects of Meeting 2007 and Later Emission and Fuel Content Standards for Medium and Heavy Freight Trucks: Projections to 2025}

\subsection{Current State of Technology}

\subsubsection{Standards and Test Procedures through 2004}

Beginning with the 1998 model year and effective through model year 2003, federally certified heavy-duty diesel engines are subject to the following emission standards (units of g/bhp-h):

\footnotetext{
\begin{tabular}{cccc|}
\hline Total HC & CO & NO $_{\mathbf{x}}$ & PM \\
\hline 1.3 & 15.5 & 4.0 & $0.10^{\mathrm{a}}, 0.05^{\mathrm{b}}$ \\
\hline
\end{tabular}

a Applicable to over-the-road heavy-duty diesel trucks and truck tractors.

b Applicable to heavy-duty transit buses; 0.05 certification value must meet $0.07 \mathrm{~g} / \mathrm{bhp}-\mathrm{h}$ in use.
}

The corresponding California standards, effective as of model year 1996, are:

\begin{tabular}{|ccccc|}
\hline Non-Methane HC & TOTAL HC & CO & NO $_{x}$ & PM \\
\hline 1.2 & 1.3 & 15.5 & 4.0 & 0.05 \\
\hline
\end{tabular}

As of 2004, California and federal standards for $\mathrm{NO}_{\mathrm{x}}$ will be harmonized at the following increased stringency levels (manufacturer selects compliance option):

$$
\begin{array}{lll}
\text { OPTION 1: } & \mathrm{NMHC}+\mathrm{NO}_{\mathrm{x}}=2.4 & \mathrm{NMHC} \mathrm{n} / \mathrm{a} \\
\text { OPTION 2: } & \mathrm{NMHC}+\mathrm{NO}_{\mathrm{x}}=2.5 & \mathrm{NMHC}=\mathbf{0 . 5}
\end{array}
$$

(The second option corresponds to a $\mathrm{NO}_{\mathrm{x}}$ standard of approximately $2.0 \mathrm{~g} / \mathrm{bhp}$-h, which is equal to a $50 \%$ reduction from the prior year.) Through 2003, levels must be certified to 10 years or 110,000 miles (whichever comes first) for vehicles up to $19,500 \mathrm{lb} \mathrm{GVW}$, to 10 years or 185,000 miles for vehicles weighing between 19,500 and $33,000 \mathrm{lb}$, and to 10 years or 290,000 miles for vehicles weighing more than 33,000 lb. Emission warranties must be honored for five years or 50,000 miles. Beginning in 2004, although the warranty period/accrual remains the same, the certification values for the 33,000-pound and higher GVW ratings increase to 13 years or 435,000 miles. Note that, pursuant to a consent decree regarding in-use violation of existing standards that was reached by EPA, the U.S. Justice Department, and truck engine 
manufacturers, all 2004 requirements have been moved forward to October 2002, for the subset of manufacturers that signed the decree and have been found guilty of this violation. Most diesel engines have already demonstrated that they are capable of meeting the 2004 non-methane hydrocarbon (NMHC) limits with engine parameter modifications, since diesel fuel combusts efficiently and is characterized by low volatility/minimal evaporation. However, the $\mathrm{NO}_{\mathrm{x}}$ component of the new standard poses a more formidable challenge because of the requirement to simultaneously meet the stringent 1998 PM limits. There is a physical trade-off between PM and $\mathrm{NO}_{\mathrm{x}}$ emissions such that, ceteris paribus, if one is controlled to a low level, the other increases.

The EPA transient emission certification cycle (FTP) for heavy-duty truck engines, codified in CFR Title 40, Part 86.1333, is shown in Figure 4. Emission testing is performed by using a DC or AC electric engine dynamometer. The four phases of the cycle represent light urban traffic conditions with frequent stops and starts (the New York Non-Freeway [NYNF] component); crowded urban traffic with few stops (Los Angeles Non-Freeway [LANF] component); crowded expressway traffic in high-speed, "saw-tooth" mode (Los Angeles Freeway [LAFY] component); and repetition of the NYNF. The cycle is conducted twice - the first time from cold shutdown and the second with a warm start after an engine-off time of 20 minutes as soon as the first run has been completed. The 1,200-s (20-min) run time for each cycle would cover an on-road distance of approximately $10.3 \mathrm{~km}(6.4 \mathrm{mi})$ at an average speed of $30 \mathrm{~km} / \mathrm{h}(19 \mathrm{mph})$. Recently, a chassis dynamometer urban driving schedule has been added to 40 CFR Part 86 because of the increasing amount of heavy-duty testing that is being performed on such equipment. The profile of this cycle mimics much of the FTP, but it is only $1,060 \mathrm{~s}$ in duration and covers only $8.9 \mathrm{~km}$ at an average speed of $30.4 \mathrm{~km} / \mathrm{h}$.

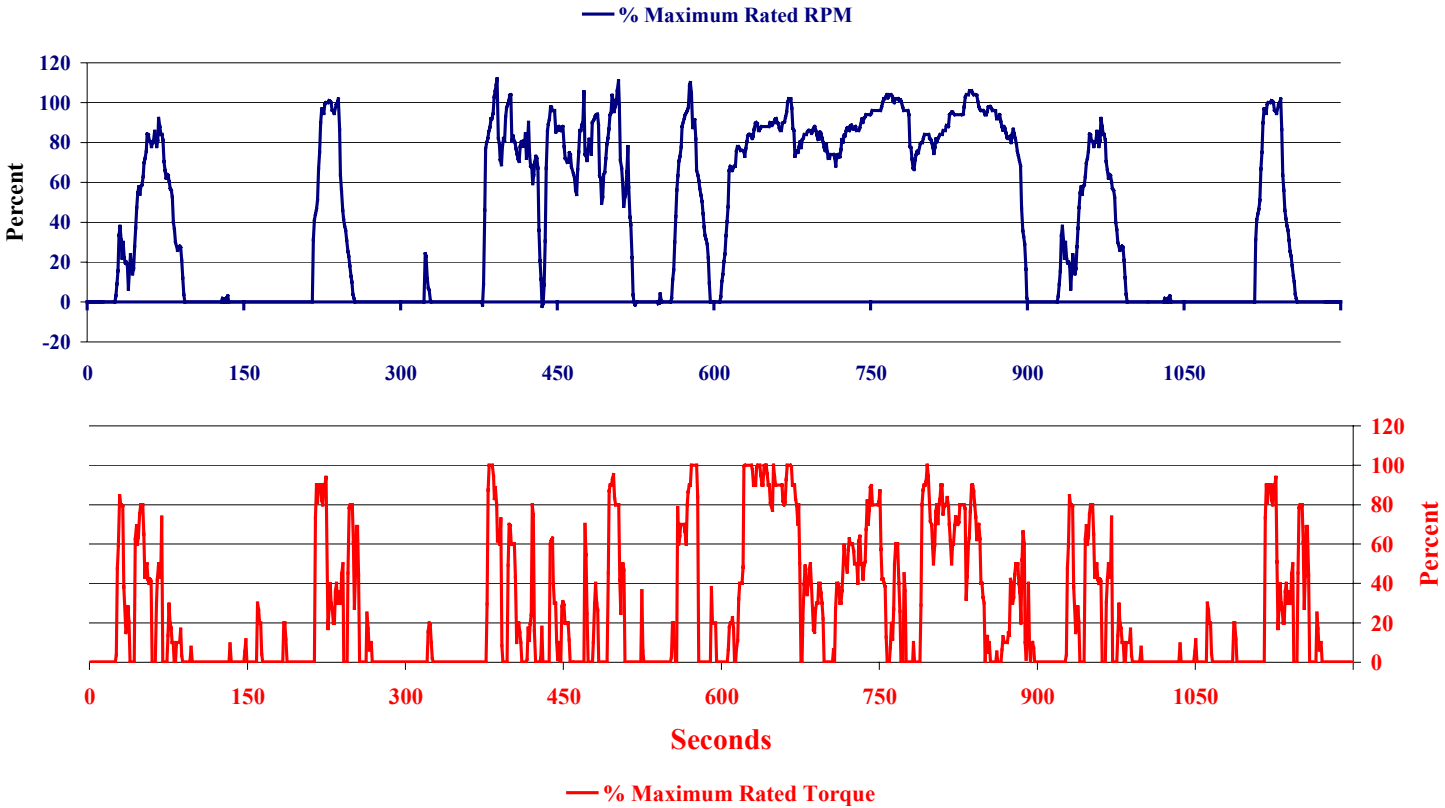

Figure 4 FTP Transient Cycle 


\subsubsection{Engine/Combustion Controls and Equipment Retrofits}

Successful commercialization of increasingly sophisticated computer-assisted common rail direct-injection designs, applied primarily to light-duty diesel engines, resulted in significant breakthroughs in diesel engine fuel and combustion management during the 1990s. This development was on par with the transition to full fuel injection technology for spark ignition engines and enabled a much greater degree of emission control within the engine than was possible under the previous indirect injection (swirl chamber) approach to diesel fuel management. Engine manufacturers have generally been able to achieve the 1998-2003 standards by combining higher fuel injection pressures, for better atomization and thus more complete burnup of combustion particles, with cooled exhaust gas recirculation for engine-out $\mathrm{NO}_{\mathrm{x}}$ control (cooler combustion produces less $\mathrm{NO}_{\mathrm{x}}$ ). They have also found that adding a supplementary sulfur-tolerant oxidation catalyst can further decrease or virtually eliminate the soluble organic fraction of tailpipe particulate mass and number at normal operating temperatures.

To bring socially sensitive heavy diesel vehicles (such as older large transit and school buses operating in urban areas) into compliance with current standards, the application of retrofit devices - especially catalytically regenerated particulate traps and/or oxidation catalysts — is on the increase. Using traps requires the availability of ultra-low-sulfur $(\approx 15 \mathrm{ppm})$ diesel fuel, while applying oxidation catalysts generally does not.

\subsubsection{Present and Near-Term Prospective Exhaust Controls (including aftertreatment)}

The EPA has expressed considerable confidence that the combined technologies of catalytic particulate traps and $\mathrm{NO}_{\mathrm{x}}$ adsorbers can meet 2004 and later heavy-duty diesel standards on vehicles equipped with OEM engines (EPA 2000). The $\mathrm{NO}_{\mathrm{x}}$ adsorber acts as a retaining reservoir for $\mathrm{NO}_{\mathrm{x}}$ emissions, stored as nitrogen dioxide following direct exhaust $\mathrm{NO}$ oxidation over a catalyst, until a vehicle's exhaust stream becomes sufficiently oxygen poor (momentarily fuelenriched) to promote reduction to $\mathrm{N}_{2}$; the adsorbed nitrogen dioxide is then released for conversion to nitrogen and carbon dioxide over a three-way reduction catalyst bed. Computercontrolled metering of the enriched exhaust stream is believed to minimize excess fuel loss: current best performance for prototype adsorbers averages 2-3\% excess fuel during pre-reduction enrichment events. These systems appear to function most effectively at exhaust temperatures between $200^{\circ} \mathrm{C}$ (approximate catalyst "light-off" temperature) and $450^{\circ} \mathrm{C}$, which represents the exhaust temperature range for over $90 \%$ of most diesel engine operations. However, for the reduction catalyst to function reliably (assuming that it is based, as at present, on catalytic washcoats of precious metal — rhodium and platinum), low-sulfur fuel will be required. Also, because certification testing will begin before after-treatment devices reach full operating temperature, diesel vehicles will have higher initial emission transients ("cold starts"), as have been problematic for years in spark ignition engines. (At the current diesel emission standards, cold transient and stabilized emission rates are virtually identical.) Even very low levels of fuel sulfur can cause sulfates to build up on the adsorber surface, inexorably impairing its efficiency unless a high temperature $\left(>500^{\circ} \mathrm{C}\right)$ transient can be generated in the exhaust to induce the sulfate to mobilize. If desulfation must be performed frequently, as is the case with fuel containing more than $15 \mathrm{ppm}$ sulfur, overall performance is likely to degrade over time as a result of reduced 
durability and sintering of the coating. Also, regular desulfation can produce undesirable odiferous compounds, such as hydrogen sulfide $\left(\mathrm{H}_{2} \mathrm{~S}\right)$, that may have to be "cleaned up" by a supplementary oxidation catalyst before leaving the tailpipe.

In dual adsorber/catalytic regenerating trap concepts currently under review, the particulate matter treatment occurs first (upstream) such that the adsorber works with a NO-rich but PMdepleted exhaust gas flow. One question is whether this type of arrangement - with the addition of an adsorber for sulfur oxides positioned downstream of the trap but upstream of the $\mathrm{NO}_{\mathrm{x}}$ controls - could successfully intercept sufficient sulfur and sulfate particles to permit acceptable and long-lived high-sulfur-tolerant operation of the overall adsorber/reduction catalyst system. The EPA has examined the mechanics of this system and has not been persuaded that catalyzing particulate traps with $\mathrm{SO}_{\mathrm{x}}$ adsorbers can intercept enough of the sulfur in diesel fuels with a sulfur content greater than $15 \mathrm{ppm}$ to sustain $\mathrm{NO}_{\mathrm{x}}$ adsorber operation at the required control efficiency (DOE 2000a). Also, $\mathrm{SO}_{\mathrm{x}}$ adsorbers would likely have to increase in volume approximately proportional to average fuel sulfur content, rendering them impractical at a sulfur content above $30 \mathrm{ppm}$ or so.

\subsubsection{Additional Technologies Available Today and in the Near Future}

Other near-term proposals for $\mathrm{NO}_{x}$ control — some of which are already in limited use include selective catalyst reduction (SCR) by means of fuel mixing with a compound (such as urea) that promotes chemical reduction, direct excess nitrogen injection into the combustion chamber, and non-thermal plasma-assisted catalysts. Caterpillar Corp. has recently claimed a "breakthrough in engine technology" that couples a hydraulically activated, electronically controlled unit injector fuel system with a proprietary "advanced combustion emissions reduction technology." Caterpillar claims that the combined systems will enable an emission treating system in the company's on-highway truck diesel engines that (1) can meet 2007 and later emission standards and (2) is far simpler than other available or developing options (Caterpillar, Inc., 2001). Speculation is that the control strategy Caterpillar is developing will involve $\mathrm{NO}_{\mathrm{x}}$ reduction with plasma-assisted catalysis (see below) (Pacific Northwest National Laboratory 2001).

Although touted as an effective retrofit option, we do not believe that, beyond rigidly controlled centrally refueled fleets, SCR has a long-term future in the trucking industry. Originally disseminated as a means for stopgap compliance with the consent decree manufacturers signed to avoid litigating the in-use high $\mathrm{NO}_{\mathrm{x}}$ excursions EPA discovered to be a "deliberate" operating strategy, SCR requires that manufacturers add a separate reservoir of urea, up to $25 \mathrm{gal}$ in the case of heavy-duty diesel trucks, to the fueling system. Moreover, without closed-loop combustion control, large amounts of ammonia $\left(\mathrm{NH}_{3}\right)$ can be released ("ammonia slip") as a by-product of the $\mathrm{NO}_{\mathrm{x}}$ reduction reaction. Ammonia has an unpleasant odor and can form large quantities of secondary fine particulates when present with the nitrate and sulfate ions found in vehicular exhaust streams. Truckers have little incentive (save deliberately programmed performance degradation or overall loss of engine functionality) to ensure that the urea is "topped up" - and when the urea reservoir is exhausted, catalytic $\mathrm{NO}_{\mathrm{x}}$ reduction no longer occurs. This technology holds little promise of ever being a "value-added" solution to stringent mobile source $\mathrm{NO}_{\mathrm{x}}$ control. 
Injection of a nitrogen-enriched combustion air stream in lieu of exhaust gas recirculation has two advantages: (1) better control of combustion air properties (as recirculated exhaust often contains undesirable constituents that can impair efficient compression) and (2) better management of combustion temperature. Moreover, a higher nitrogen-to-oxygen ratio can retard the rate of $\mathrm{NO}_{\mathrm{x}}$ formation in the cylinder. The principal drawback in the near term is the experimental nature of this technology: unless intake air can be split into nitrogen-enriched and oxygen-enriched streams on board, say, by some yet-to-be-perfected osmotic process, nitrogen cylinders would have to be incorporated, raising the same inadequate restocking issues as SCR. However, with a developmental time horizon of 2025, small, lightweight osmotic membranes could be perfected sufficiently to improve long-term prospects for this option. The same can be said of non-thermal plasma-assisted catalysts, which, when perfected at lower voltage and power requirement than at present, would generate NO-oxidizing ions across charged metal plates in lieu of through-oxidation catalysts, thus saving the expense of precious metals.

At the lighter end (10,000-14,000 lb) of the heavy-duty slate, a way for truck and engine manufacturers both to meet stringent $\mathrm{NO}_{\mathrm{x}}$ and $\mathrm{PM}$ emission standards and to bypass the uncertainties about future diesel fuel properties is to commit to producing more clean-burning gaseous-fueled trucks. This strategy would also enable these manufacturers to obtain sufficient "low-emission bin" certifications to offset the potentially higher-emission certifications for their diesel and gasoline offerings.

Gasoline-fueled vehicles in the lighter classes (up through 14,000 lb), most of which are already catalyst-equipped, seem destined to be able to meet regulated standards by 2005, but if there is an emerging preference for diesel in these categories, compliance is not assured for those vehicles. Thus, CNG and, potentially, dedicated propane-fueled trucks could meet an important need in this market segment, unless spark-ignition engines regain dominance and gasoline is their fuel of choice.

Note that engine tuning to control $\mathrm{NO}_{\mathrm{x}}$ to ever-more stringent levels works against compliance (by combustion regulation alone) with the carbon monoxide standard ( $15 \mathrm{~g} / \mathrm{bhp}-\mathrm{h})$ for heavy-duty diesels. Thus, the oxidation catalyst now applied for particulate reduction may also prove essential to future maintenance of regulated $\mathrm{CO}$ limits. 


\subsection{Impact of 2007 and Later Standards}

\subsubsection{Timing of Phase-In for Both Vehicular Emission Limits and Fuel Properties}

Beginning in the 2007 model year and phasing in to $100 \%$ over a four-year period, all federally certified on-road heavy-duty diesel engines will be subject to the following emission limits (g/bhp-h):

\begin{tabular}{|c|c|c|c|c|}
\hline Non-Methane $\mathrm{HC}^{\mathrm{a}}$ & co & $\mathrm{NO}_{\mathrm{x}}$ & PM & $\mathrm{HCHO}^{b}$ \\
\hline 0.14 & 15.5 & 0.2 & 0.01 & 0.016 \\
\hline
\end{tabular}

The required minimum phase-in rate for each manufacturer's new production fleet is as follows:

2007: 25\%; 2008: 50\%; 2009: 75\%; 2010: 100\%.

For heavy-duty gasoline-fueled vehicles in the 8,500-14,000-lb gross vehicle weight (GVW) classes (i.e., $2 \mathrm{~b}$ and 3 ), the corresponding standards (g/bhp-h) are:

\begin{tabular}{|lccccc|}
\hline Weight (Ib) & NMHC & CO & NO $_{\mathbf{x}}$ & PM & HCHO \\
\hline $8,500-10,000$ & 0.195 & 7.3 & 0.2 & 0.02 & 0.032 \\
$10,000-14,000$ & 0.230 & 8.1 & 0.4 & 0.02 & 0.040 \\
\hline
\end{tabular}

Full compliance with the above standards is required in the 2008 model year. In the case of both $\mathrm{NO}_{\mathrm{x}}$ and $\mathrm{PM}$, this represents a 90\% reduction from 2004 standards and a better than $98 \%$ reduction from the standards in place in 1988. The EPA (EPA 2000) leaves no doubt in its Regulatory Impact Analysis (RIA) for these 2007 and later truck standards that it holds diesel fuel of a very low sulfur content (in any case, no greater than about $15 \mathrm{ppm}$ ) to be an indispensable prerequisite to the attainment of these standards. The reason is that the control technologies the RIA identifies as being capable of achieving required reductions in tailpipe emissions will not function properly, except with low-sulfur fuel. We should therefore consider that the general availability of such fuel in a time frame consistent with the schedule for phasing in the new standards will be a given, or, conversely, that the new exhaust limits will be delayed if litigation or other circumstances delay the availability of such fuel. For this analysis, we take the view that both low-sulfur diesel fuel and ultra-clean diesel emission control technologies that do not significantly degrade fuel economy will be available somewhat ahead of the mandated schedule, enabling engine manufacturers who so choose to take advantage of advance banking incentives for their out-year fleet offerings. A force countervailing such incentives is the strong customer specification-driven nature of the heavy-duty truck market, which renders this already lowvolume product even less subject to emission control cost spreading since each manufactured unit may be uniquely specified. 


\subsubsection{Technologies Expected to be Proven/Capable of Commercialization by 2006}

For as long as the sulfur content of diesel fuel remains at or near current levels, sulfurtolerant $\mathrm{NO}_{\mathrm{x}}$ and $\mathrm{PM}$ control methods will be required. Urea-based selective catalyst reduction for $\mathrm{NO}_{\mathrm{x}}$ control is already in use in some heavy-duty fleets, although fleet managers generally assume the responsibility for ensuring on-board availability of urea, not vehicle operators. Literature is very sparse with respect to systematic evaluation of the effectiveness of fleet SCR programs, but a recurring problem observed in some open-loop SCR retrofit applications is "ammonia slip," in which excess reductant (urea) builds up on the catalyst surface and is eventually rejected as high ammonia exhaust transients. Recent tests have shown the ability to control this problem (Sluder and West 2002) and raised the possibility that the ammonia needed for the catalytic reduction reaction can actually be produced on-board from the propulsion fuel, thus obviating the urea reservoir and taking the vehicle operator "out of the loop" of emissions control. Unfortunately, the fuel economy penalty with these prototype units generally exceeds 15\% (Ogunwumi et al. 2002). Most $\mathrm{NO}_{\mathrm{x}}$ retrofit programs are not expected to survive after 15 ppm sulfur fuel becomes universally available and the requirements of the EPA consent decree on $\mathrm{NO}_{\mathrm{x}}$ emission compliance are met. However, investigations are under way to provide catalytic reduction through other agents, including the use of injected diesel fuel itself as a reactant (socalled hydrocarbon or volatile organic compound selective catalyst reduction). Like on-board ammonia generation, this approach currently bears a significant fuel economy penalty. Whatever $\mathrm{NO}_{\mathrm{x}}$ reduction technique is ultimately adopted, closed-loop (closed crankcase) emission controls will become standard by 2006 on all sizes of diesel engine/powertrain systems, just as they have been for many years in spark-ignition vehicles.

For PM control, retrofit with regenerating exhaust particulate traps is well under way for heavy-duty vehicles - such as school and transit buses, refuse haulers, and pick-up and delivery trucks - that operate predominantly in urban areas. These retrofits require low-sulfur (i.e., less than $50 \mathrm{ppm}$ ) diesel fuel for full control effectiveness. Activity is especially vigorous in southern California, where such retrofits are eligible for funding under the Carl Moyer emission mitigation program, and in New York City, where transit buses have undergone, or will soon be undergoing, retrofit.

\subsubsection{Pollutants for Which Final Control Set Remains Undefined or Flexible}

As implied above, there remains a wide choice of options for advanced $\mathrm{NO}_{\mathrm{x}}$ control, and assuming availability of $15 \mathrm{ppm}$ sulfur diesel fuel, no one technique has yet been identified as superior. Heavy-duty engines must now be emission-certified to as many as 435,000 miles of operation (Class 7 and 8), so durability of the emission control equipment set is critical. The EPA endorses the $\mathrm{NO}_{\mathrm{x}}$ adsorber-based solution, but without a commercial product, estimates of effective service life, maintenance intervals, and costs for these systems are highly speculative. Perfecting an SCR system employing clean diesel fuel itself (rather than urea) as the reducing agent, such that $90 \% \mathrm{NO}_{\mathrm{x}}$ removal is achieved (nothing approaching this level is now in view), could result in a control platform that does not require operator intervention and is lighter-weight and more reliable than adsorbers or plasma catalysts. For the lighter (Class $2 b-3$ ) heavy-duty 
trucks, migration of a portion of that fleet to hybrid electric power could obviate some of the Stage IV controls needed for conventional vehicles. Thus, joint control of $\mathrm{NO}_{\mathrm{x}}$ and particulates in 2b-3 diesel-electric hybrids may be achievable with exhaust gas recirculation and an oxidation catalyst (and possibly passive SCR) as the only required exhaust aftertreatment.

\subsection{Onboard Fuel Efficiency Effects of 2007 and Later Standards}

Although the $21^{\text {st }}$ Century Truck program has articulated a fuel economy penalty goal of no more than five percent to achieve 2007 and later emission standards (DOE 2000a, p. 4-14), truck and bus engine manufacturers are determined to meet these stringent standards without any net loss in fuel efficiency because customers would strongly resist a loss in fuel economy, especially given past expectations of performance. Meeting this need will require that any new parasitic or system efficiency losses attributable to additional emission control devices and techniques be offset by fuel economy gains across all truck size classes. In Tables 1-3, we indicate that fuel efficiency gains will remain equal to or slightly ahead of emission-control-related fuel penalties, such that no new model-year vehicle will prove inferior in performance or fuel consumption to its predecessors per unit of work output. Thus, the following discussion should be considered only in light of the net fuel economy information in Tables 1-3, which for any model year chosen should show either a gain or zero overall loss. However, obstacles to achieving this goal remain formidable, as documented in recent technical papers cited herein.

\subsubsection{Speculation on Parasitic Losses}

The incremental mass of add-on equipment for treating emissions, which is variable by engine size/displacement but increasingly subject to minimization through the use of advanced materials, will impose a fuel economy penalty on heavy diesel trucks that would otherwise not have occurred. There are other possible sources related to the control of exhaust emissions that would sacrifice fuel efficiency. A common technique for $\mathrm{NO}_{\mathrm{x}}$ control generally modulated through engine or manifold vacuum ported to the cylinder intake valves is recirculating some fraction of cylinder-out gas from the exhaust manifold back to the combustion chamber after compression by a supercharger and cooling by an intercooler. On light-duty vehicles, before closed-loop control and real-time on-board diagnostics became standard, carbon build-up in the vacuum lines could impair the recirculation process, resulting in an increased pumping load. More importantly, as mechanical controls occasionally allow EGR application to drift beyond $50 \%$, soot formation increases as excess fuel is needed for combustion (Guzman 1997). Given the introduction of electronic closed-loop control and mature EGR technology in heavy diesel trucks, this problem is not expected to recur, and placing a turbine in the exhaust stream can meet the needs of supercharger air compression.

Although catalyst diesel particulate traps should be fully automated with respect to burnoff of collected matter and recharging, backpressure will build up before all required cleaning functions (including ash blowout and removal) are triggered by a sensor. Excess fuel consumption during this period could reach $2 \%$ (DOE 2000b). 
$\Delta$

\begin{tabular}{|c|c|c|c|c|c|c|c|c|c|c|c|c|c|}
\hline 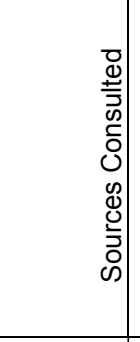 & & & & & & & & & & 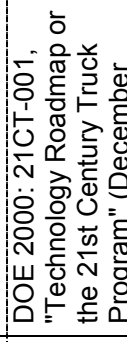 & 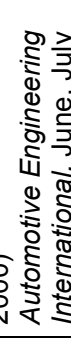 & 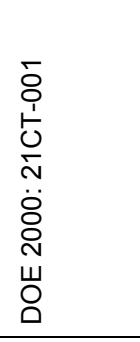 & 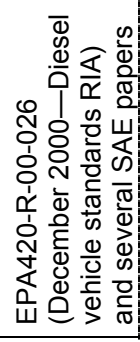 \\
\hline 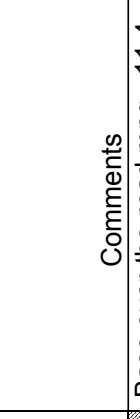 & 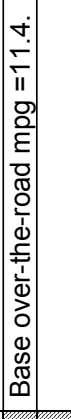 & & & & 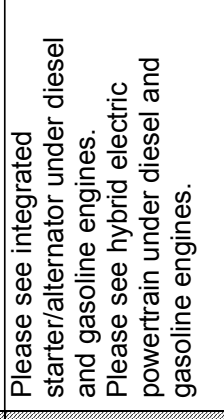 & \multicolumn{3}{|c|}{ 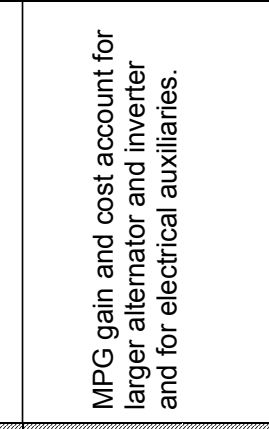 } & 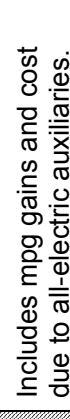 & 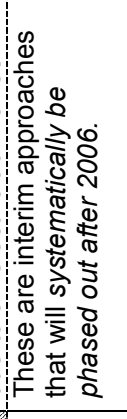 & \multicolumn{2}{|c|}{ 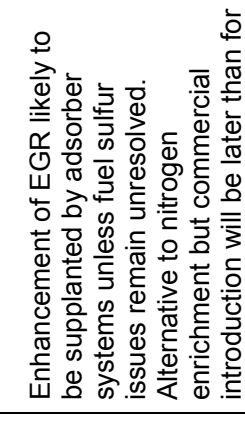 } & 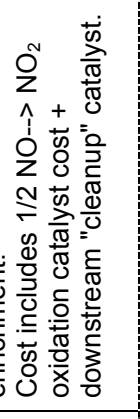 \\
\hline 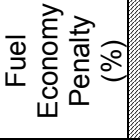 & & & & & & & & & & mp & $\stackrel{L}{0}$ & $\stackrel{T}{-}$ & $\stackrel{+}{\sim}$ \\
\hline 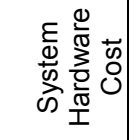 & $\begin{array}{l}8 \\
0 \\
0 \\
\oplus\end{array}$ & : & $\frac{\infty}{\infty}$ & 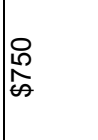 & & 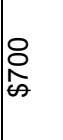 & $\begin{array}{l}\stackrel{8}{N} \\
\frac{-}{\infty}\end{array}$ & 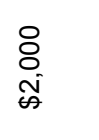 & $\begin{array}{l}8 \\
0 \\
0 \\
0\end{array}$ & 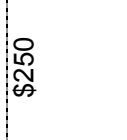 & 怘 & $\frac{8}{\delta}$ & 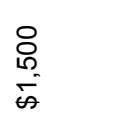 \\
\hline 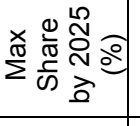 & $\infty$ & b & $\mathfrak{R}$ & 음 & & $\stackrel{\sim}{\sim}$ & $\stackrel{\llcorner}{\sim}$ & $\stackrel{6}{\longrightarrow}$ & $\stackrel{10}{\leftarrow}$ & 우 & $\begin{array}{l}\text { *. } \\
\text { 总 }\end{array}$ & $\stackrel{2}{N}$ & $\stackrel{R}{\sim}$ \\
\hline 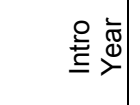 & 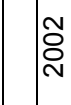 & है & ষ্ণ & 怘 & & ஜ & ஜ̊ & $\stackrel{\sim}{\grave{N}}$ & $\stackrel{\circ}{\circ}$ & & ஜั & 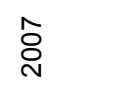 & ڤิे \\
\hline $\begin{array}{l}0 \\
\text { D } \\
\Sigma\end{array}$ & ํํ & $\stackrel{\text { }}{\mathrm{v}}$ & $\stackrel{\sim}{\sim}$ & 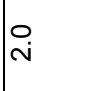 & & i. & i̊ & $\stackrel{\circ}{\circ}$ & 움 & & & & \\
\hline 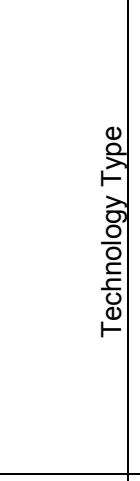 & & 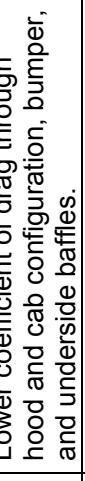 & 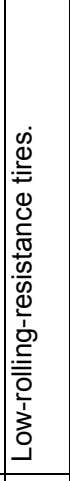 & 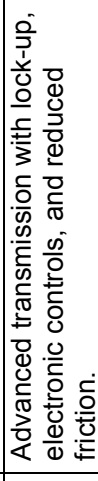 & 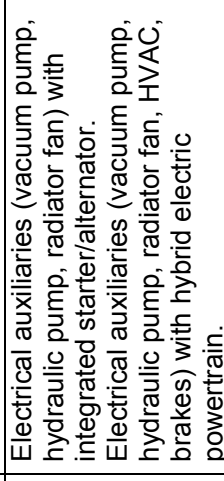 & 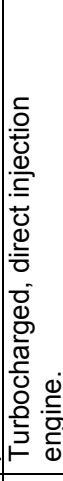 & 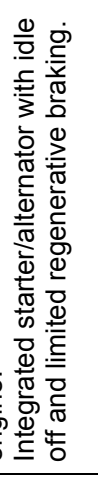 & 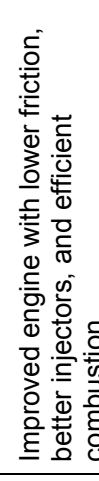 & 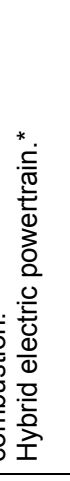 & 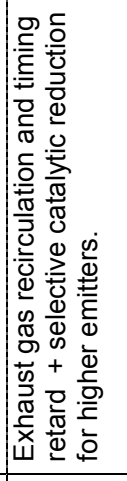 & 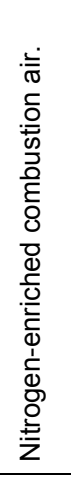 & 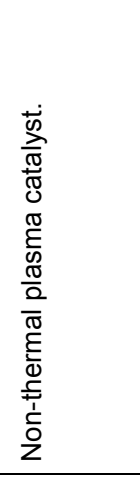 & 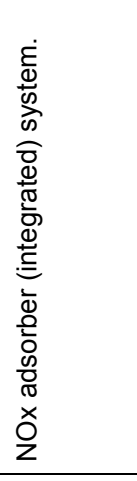 \\
\hline 恋 & - & - & - & - & $=$ & - & $=$ & $\equiv$ & $\geq$ & - & $=$ & $\equiv$ & $\geq$ \\
\hline 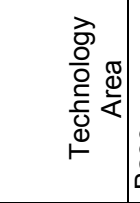 & 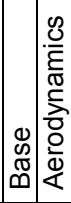 & 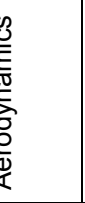 & 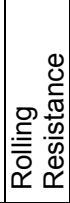 & 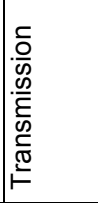 & 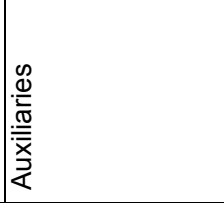 & 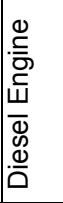 & & & & 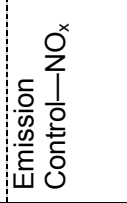 & & & \\
\hline
\end{tabular}




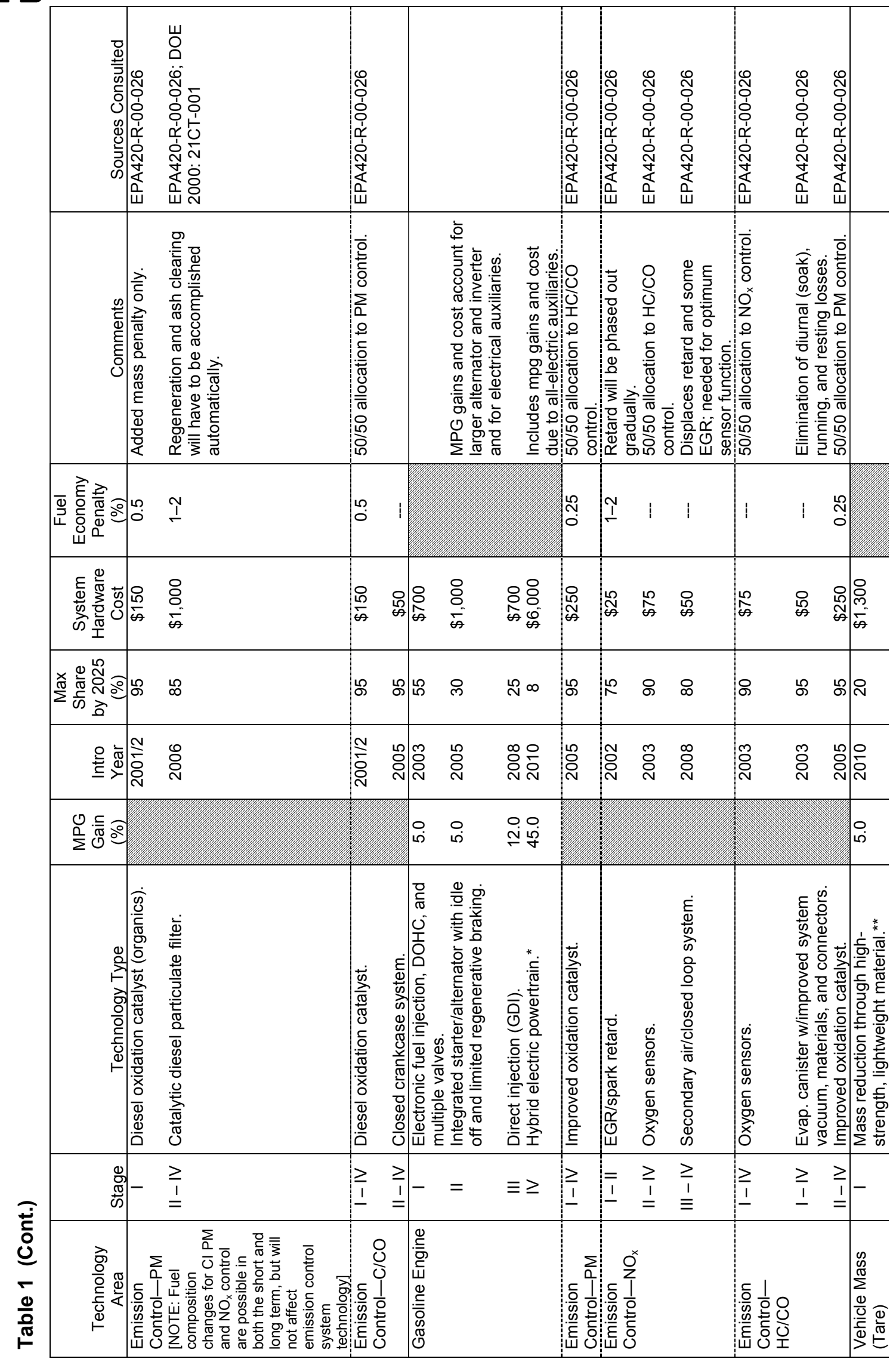




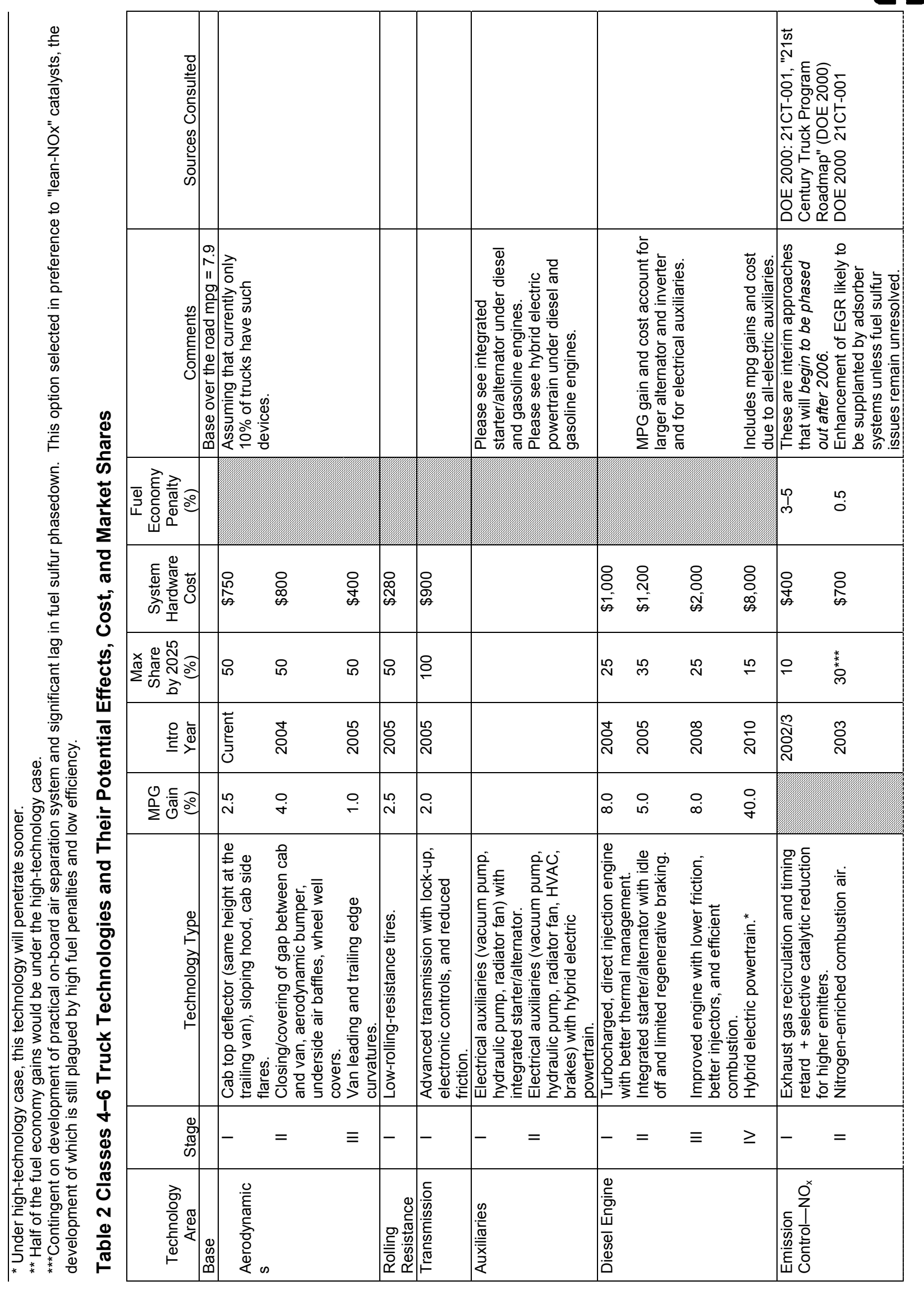


$\Delta$ 


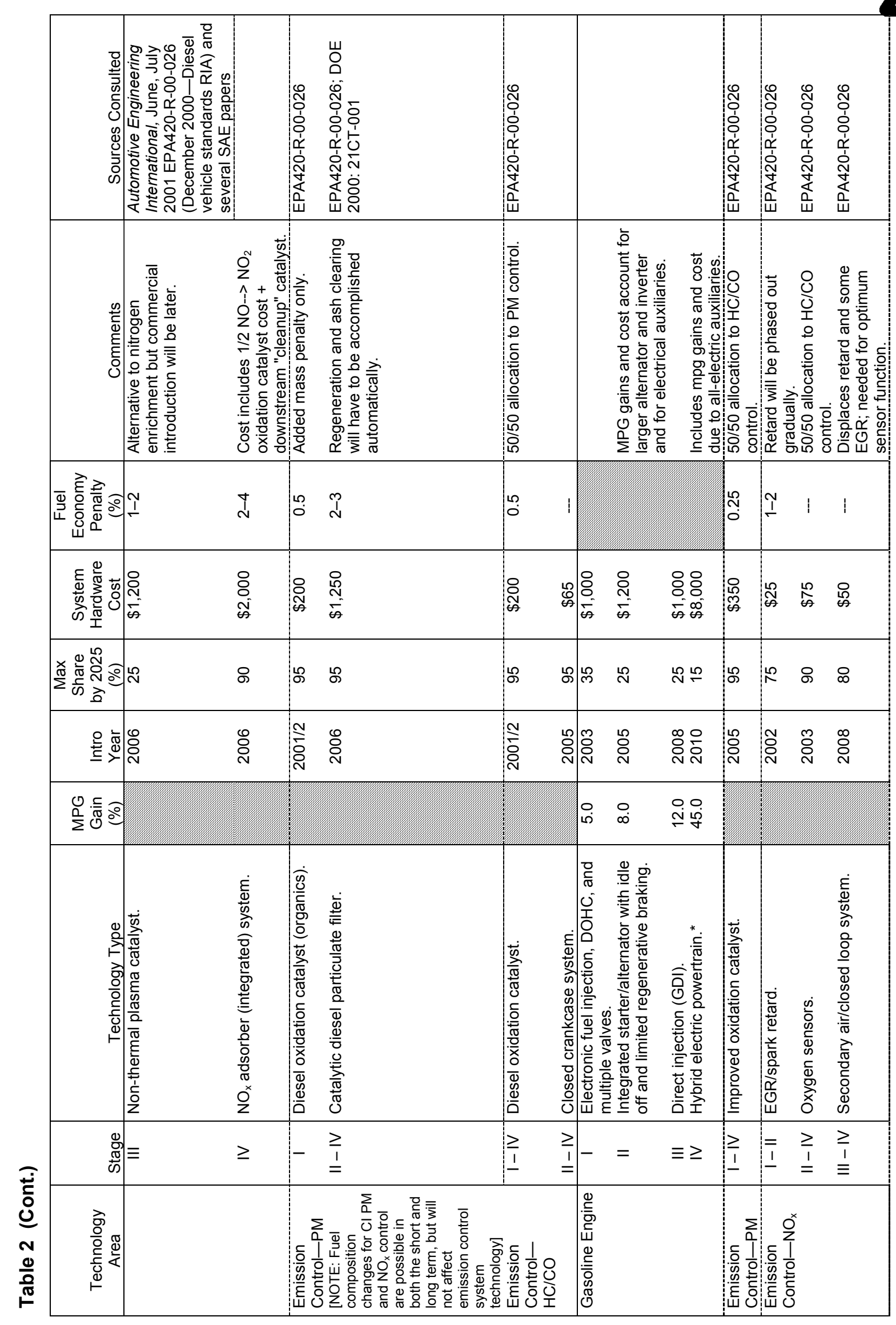




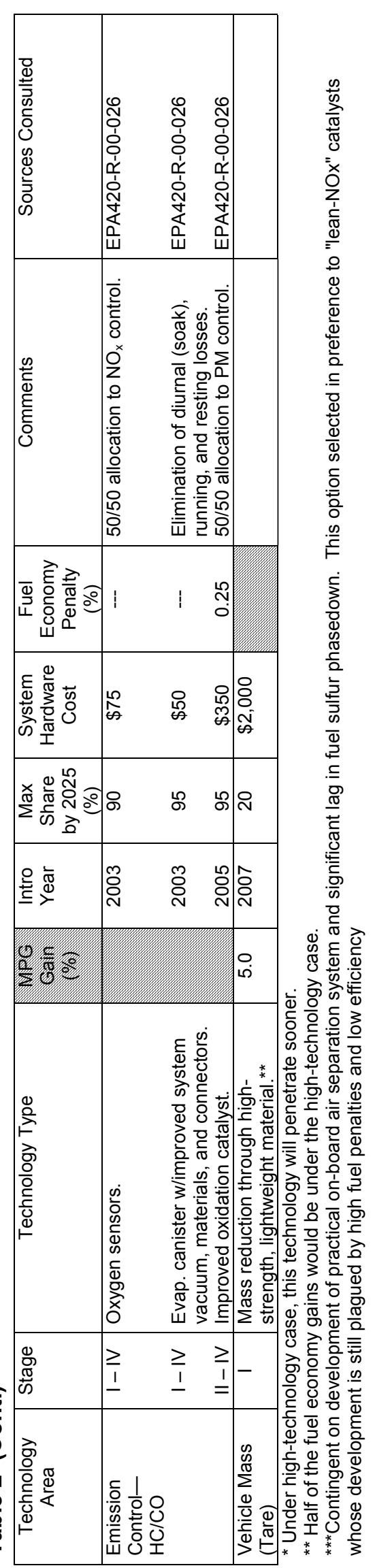




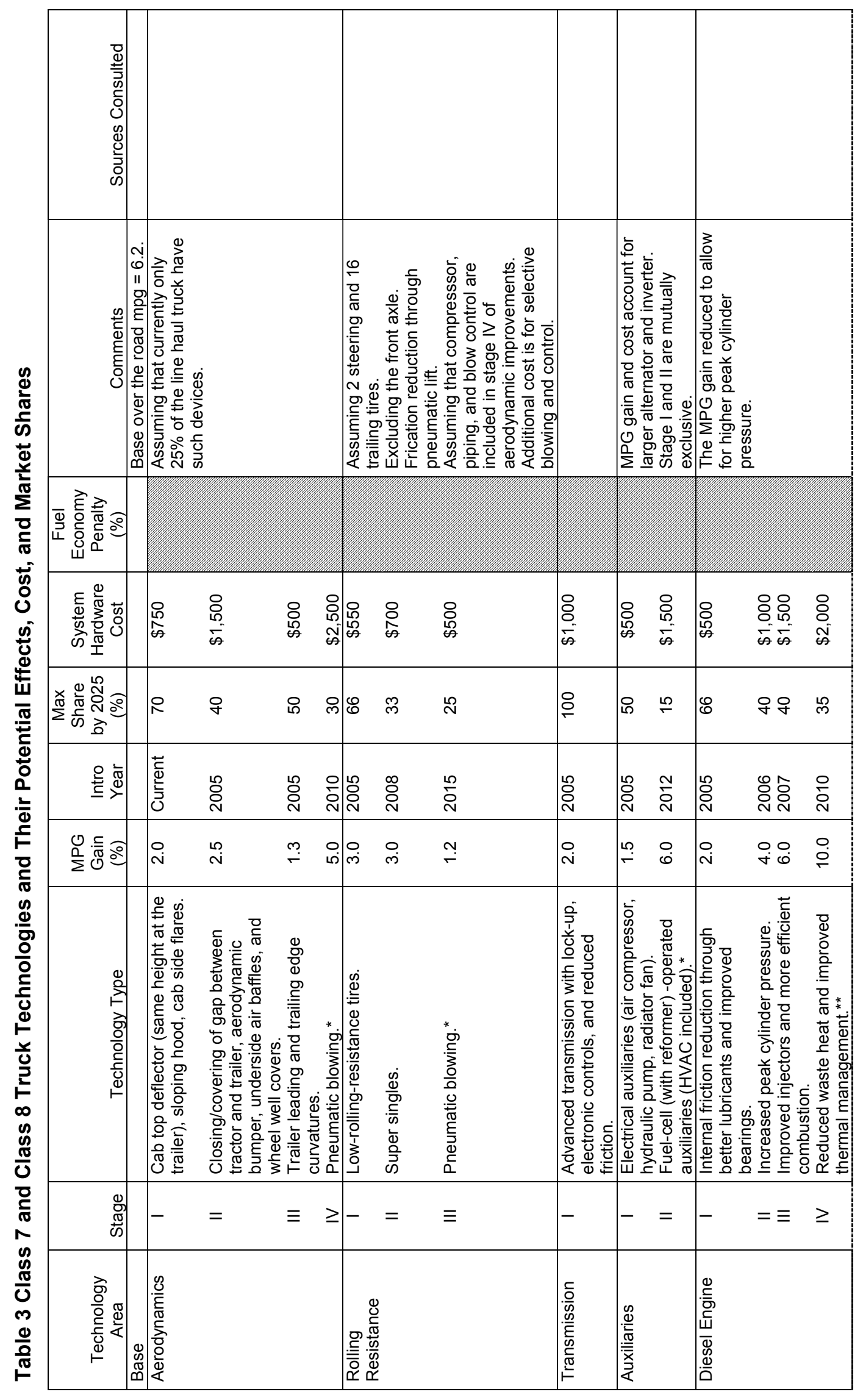




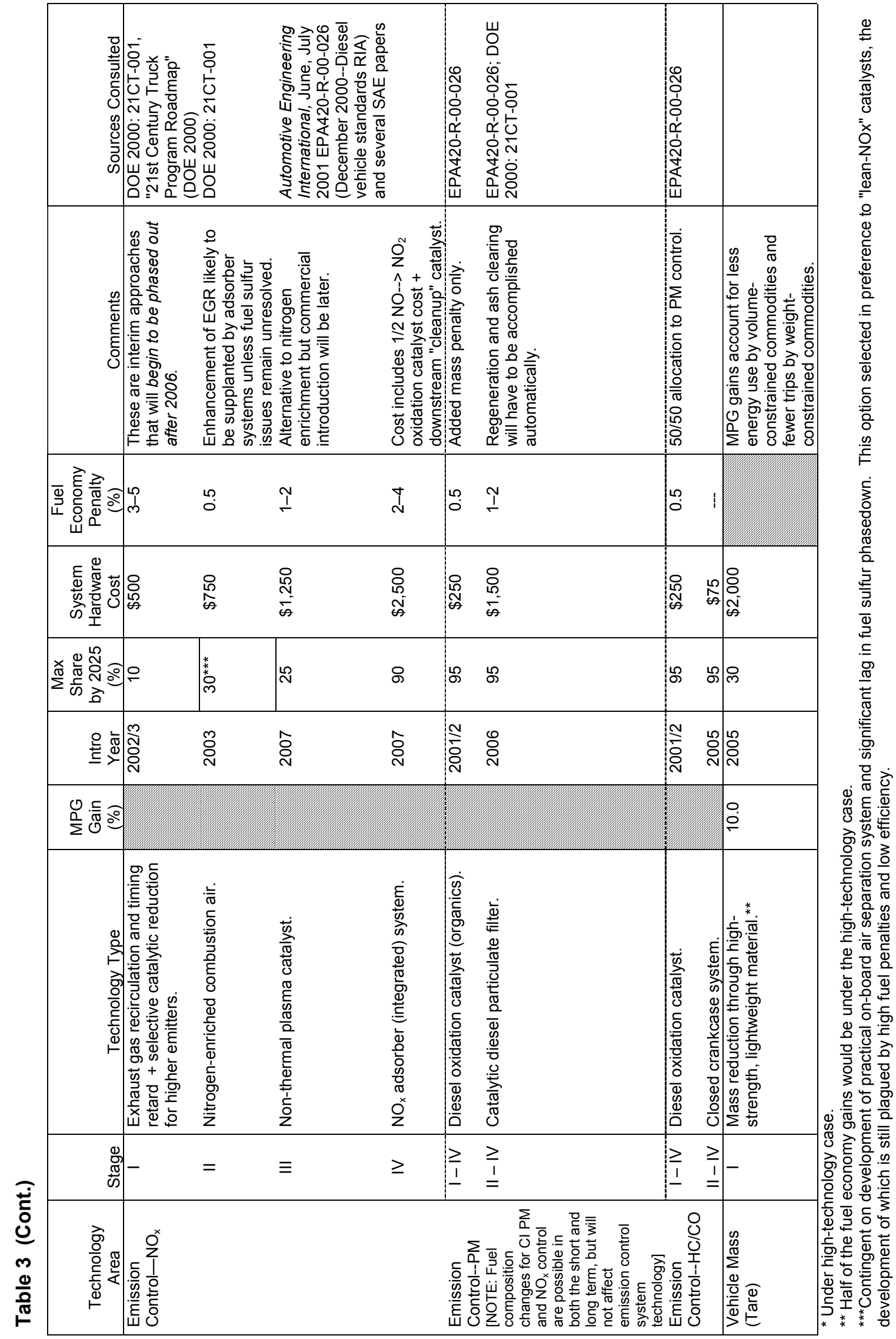


$\mathrm{NO}_{\mathrm{x}}$ adsorber regeneration will also require injection of small amounts of diesel fuel for light off and desorption of stored NO for downstream catalysis under rich-burn conditions. This process may result in additional fuel use beyond combustion for propulsion of $2-4 \%$, depending on system maturity (EPA 2000, pp. III-35 through III-48).

The incremental energy requirement for periodic desulfation of the $\mathrm{NO}_{\mathrm{x}}$ adsorber and catalyst at a temperature of up to $750^{\circ} \mathrm{C}$ - a procedure necessary for proper adsorber function when fuel sulfur content exceeds about $3 \mathrm{ppm}$ - is estimated at 1-2\% (Dearth et al. 1998). This efficiency would be considerably better than what has been achieved in recent prototype testing. This efficiency does not account for the potential reduction in the cost-effectiveness of $\mathrm{NO}_{\mathrm{x}}$ removal over time due to a fall-off in adsorber efficiency caused by sintering of portions of the active catalyst matrix (Parks et al. 2002; Monroe and Li 2002).

\subsubsection{Decrease in Maximum Potential Engine Efficiency (combustion cooling, EGR)}

EGR and cooled (or $\mathrm{N}_{2}$-enriched) combustion air each has the property of diminishing the potential work output that could be obtained from the compression ignition (diesel) cycle per unit energy input if optimal temperature and fuel/air mix could be retained. Such diminution has always been interpreted as a "cost of doing business." The attributable increase in brake-specific fuel consumption has been measured, as a function of excess air introduced to the cylinder, to reach about $2 \%$ relative to best case (stoichiometric) combustion conditions before engine performance falls off dramatically (Robert Bosch GmbH 2000).

Plasma arc recharge, like NO release from an adsorber, draws on available fuel for its energy requirement. The excess fuel use penalty is up to 3\% (European Fuels News 1999).

\subsection{Technology Cost Estimates and Credits Other than Efficiency Penalties}

The capital costs of the new technologies, including amortization of $\mathrm{R} \& \mathrm{D}$, are shown in column 7 of Tables 1-3. While based on estimates documented by the U.S. EPA (2000), they incorporate a premise based on past cost studies from EPA Regulatory Impact Analyses that the EPA's approach can underestimate fully allocable cost by one-third or more. Thus, costs, where shown, are conservatively inflated 50\% above the EPA's unit estimates (i.e., a multiplier of 1.5 times fixed + variable costs). Although it is not yet field-proven, these estimated cost increments could be mitigated by a credit of $10 \%$ or more for reduced vehicular maintenance requirements because of the future use of predominantly electronic (rather than mechanical) control systems for many emission control functions. In fact, the EPA has assigned a reducedmaintenance savings credit (1999 dollars), ranging from $\$ 150$ (lighter medium-duty diesel trucks) to $\$ 600$ (heavy heavy-duty diesel trucks), to the application of 2007 and later emission-control technologies (EPA 2000, Chapter V). 


\subsection{Emerging Low-Emission Technologies and Their Prospects for Commercialization after 2010}

\subsubsection{Fuel Cells}

Fuel-cell-based propulsion is not considered a viable option for the commercial heavy truck market. Major advancements in vehicular fuel cell durability, weight, and cost will indeed occur over the next ten to fifteen years. However, it is generally conceded that the demanding peak power requirements of the heavy-duty fleet will restrict fuel cell application in commercial trucks to (1) propulsion in a subset of the light-duty fleet (i.e., trucks and vans less than 8,500 lb) and, possibly, to (2) supplemental powering of auxiliaries in a stopped heavy vehicle. The latter application is basically that of a stationary generator introduced to preclude extended engine idling (DOE 2000a). Both of these applications are expected to emerge before 2010 and accelerate penetration thereafter.

\subsubsection{Diesel Electric Hybrids}

Tables 1 and 2 indicate the anticipated time frame of introduction (about 2010) and penetration of diesel hybrid trucks into the heavy-duty fleet. Note that this technology is not considered a viable option for the heaviest trucks and tractors, and it is for only a subset of lighter heavy-duty trucks by 2025 (DOE 2000a). However, where these hybrid systems can provide power adequate for a truck's mission (recall that in a true hybrid, the heat engine will be significantly downsized and used predominantly to meet peak power requirements, in order to maximize overall efficiency gains), using all-electric auxiliaries will yield additional benefits in terms of fuel economy and emission reduction.

\subsubsection{Effects of Synthetic Diesel Fuel}

Using natural-gas-based synthetic diesel fuel with its zero-sulfur, zero-aromatic (straightchain) hydrocarbon properties will bring immediate and significant reduction in particulate, sulfate, and toxic emissions from heavy diesel trucks. The consensus is that creating a significant market for such a fuel will depend on (1) a major domestic increase in the cost and decline in the supply reliability of conventional petroleum and petroleum products and (2) the economic attractiveness of constructing large synthetic petroleum refineries at or near remote natural gas fields. The second condition would open up the opportunity to ship liquid rather than gaseous product from these fields, which would alleviate costly investment in new, often undersea, gas transmission pipelines. Serious discussions are under way to bring more of such plants on-line by 2010, and at least two gained commitments for construction start by the end of 2002 .

\subsubsection{The "All Electrically Controlled" Engine}

Generally independent of the pace of development of hybrid-electric technology, the evolution of functional control systems of heavy-duty trucks from all-mechanical to partmechanical, part-electrical, and, finally, all-electrical will proceed with the introduction of $42-\mathrm{V}$ battery systems. Significant fuel savings are possible by decoupling belt-driven devices, such as various pumps, from the engine through the use of electronically controlled electric drives. In addition, electronic control of combustion and aftertreatment could provide additional benefits to 
fuel economy and emissions. Thus, while we have not explicitly credited all-electric engine control functionality with specific benefits to emission and fuel economy in this report, neither have we assigned them separable costs, as they will be integral to truck operation on all heatengine and electrochemical propulsion pathways.

\subsection{References to Section 3}

Caterpillar, Inc., 2001, "Caterpillar's Emission-Control Technology," Automotive Engineering International, p. 30, June.

Dearth, M.A., et al. (Ford Motor Co), 1998, "Sulfur Interaction with Lean $\mathrm{NO}_{\mathrm{x}}$ Traps: Laboratory and Engine Dynamometer Studies," SAE paper no. 982595, Oct.

DOE: U.S. Department of Energy

DOE, 2000a, Technology Roadmap for the $21^{\text {st }}$ Century Truck Program: A Government-Industry Research Partnership, DOE-DOD/21CT-001, Oak Ridge, Tenn., Dec.

DOE, 2000b, Phase I Interim Data Report No. 4: Diesel Particulate Filters - Final Report, Diesel Emission Control - Sulfur Effects (DECSE) Program, Oak Ridge, Tenn., pp. 20-21; 40-41, Jan.

EPA: U. S. Environmental Protection Agency

EPA, 2000, Regulatory Impact Analysis: Heavy-Duty Engine and Vehicle Standards and Highway Diesel Fuel Sulfur Control Requirements, EPA420-R-00-026, Office of Air and Radiation, Washington, D.C., Dec.

European Fuels News, 1999, Hart Publications Europe, Inc., T.L. Wright, ed., 3:18, Sept. 22.

Guzman, H., 1997, "Understanding Exhaust Gas Recirculation Systems," 1997, AutoInc Magazine XLV:(1, 12).

Monroe, D.R., and W. Li, 2002, "Desulfation Dynamics of $\mathrm{NO}_{\mathrm{x}}$ Storage Catalysts," paper no. 2002-01-2886, presented at 2002 SAE Powertrain \& Fluid Systems Conference \& Exhibition, reprinted from Diesel Particulate Systems and Gaseous Emissions, publication no. SP-1723, SAE International, Warrendale, $\mathrm{Pa}$.

Ogunwumi, S., et al, 2002, "In-Situ $\mathrm{NH}_{3}$ Generation for SCR NO $\mathrm{N}_{\mathrm{x}}$ Applications," paper no. 200201-2872, presented at 2002 SAE Powertrain \& Fluid Systems Conference \& Exhibition, reprinted from Diesel Particulate Systems and Gaseous Emissions, publication no. SP-1723, SAE International, Warrendale, $\mathrm{Pa}$.

Pacific Northwest National Laboratory, 2001, "PNNL Reduces Noxious Emissions," Automotive Engineering International, pp. 44-46, July. 
Parks, J., et al., 2002, "Durability of $\mathrm{NO}_{\mathrm{x}}$ Absorbers: Effects of Repetitive Sulfur Loading and Desulfation," paper no. 2002-01-2880, presented at 2002 SAE Powertrain \& Fluid Systems Conference \& Exhibition, reprinted from Diesel Particulate Systems and Gaseous Emissions, publication no. SP-1723, SAE International, Warrendale, Pa.

Robert Bosch GmbH, 2000, Automotive Handbook (Fifth Edition), Stuttgart (De), p. 435 and p. 501.

Sluder, C.S., and B.H. West, 2002, "Effects of Regeneration Conditions on $\mathrm{NO}_{\mathrm{x}}$ Adsorber Performance," paper no. 2002-01-2876, 2002 SAE Powertrain \& Fluid Systems Conference \& Exhibition, reprinted from Diesel Particulate Systems and Gaseous Emissions, publication no. SP-1723, SAE International, Warrendale, Pa. 
$\Delta$ 


\section{Section 4 \\ Conclusions}

We have analyzed and presented the results of several technologies for improving energy and emissions characteristics of heavy trucks (gross vehicle weight classes $2 b-8$ ). The analysis involved estimating fuel economy impacts of these technologies, probable cost, and potential market penetration. We compiled the estimates of the impacts on fuel economy from several sources and presented the most likely estimates. Each technology was characterized on the basis of current status, regulations, and most likely production methods. On the basis of the resulting estimates in terms of costs and market penetration, we have come to the following conclusions:

- The fuel economy of heavy trucks can be improved substantially by reducing parasitic and accessory loads and using a more efficient powertrain. Some of the technologies are estimated to have high initial cost and, consequently, will penetrate niche markets.

- The fuel economy of class 8 trucks can be improved to $10 \mathrm{mpg}$ or slightly more by using the known technologies that reduce aerodynamic and rolling loads, increasing the use of lightweight materials, and improving diesel engine efficiency.

- The fuel economy of medium trucks in the classes 4-6 GVW group could be improved substantially by using a hybrid electric powertrain. However, given experience with hybrid electric cars, this option would be attractive only for trucks that have high annual use.

Nominal losses in potential maximum fuel economy and moderately higher acquisition costs are associated with the addition of (1) emission control aftertreatment equipment and (2) modified combustion management techniques for meeting impending exhaust emission standards for particulate matter, oxides of nitrogen, and (potentially) carbon monoxide. The losses associated with these techniques are expected to be offset in commercial production engines by gains in fuel economy that result from implementing the efficiency measures cited above, and so the net fuel efficiency loss compared to engines meeting less-stringent standards is expected to be zero. The leading anticipated control strategies are as follows:

- Addition of adsorber aftertreatment, in conjunction with ultra-low sulfur diesel fuel (ULSD), for compliance by medium and heavy trucks with the 2004 and later $\mathrm{NO}_{\mathrm{x}}$ standards.

- Also, if ULSD is generally available, requisite control of fine PM can be achieved by using a catalytic diesel particulate filter that (1) could gradually supplant the oxidation catalysts now (in the absence of a stringent $\mathrm{NO}_{\mathrm{x}}$ standard) widely applied and (2) may still be needed after 2007 for CO control.

- Control measures already established for gasoline-fueled light trucks and automobiles can be extended to spark-ignition light and medium heavy (classes $2 b-6$ ) trucks, given 
the availability of low-sulfur gasoline. However, application of oxidation catalysts will be much lower for the heavy (classes 5-6) end of the range because of constraints related to the size of catalyst.

As stated above, the pace at which these developments will occur is likely to be significantly affected by fuel price - and especially by a general perception that petroleum product prices will continue to rise. Exploration of market adoption of these technologies as a function of fuel cost was not a component of the current effort, but it should be incorporated in future analysis. 